\title{
Lieporų dvaras - baronų Grothusų rezidencija
}

\section{Ernestas Vasiliauskas}

Klaipėdos universitetas

Baltijos regiono istorijos ir archeologijos institutas

Herkaus Manto g. 84, LT-92294 Klaipèda

ernestas@inbox.lv

XV a. suintensyvèjo Žiemgalos regiono apgyvendinimo procesai. Tiek Livonijos dalyje nuo XV a. antros pusės, tiek Lietuvos dalyje nuo XVI a. pradèta dalyti valdas už tarnybą vasalams, bajorams, steigėsi dvarai, formavosi jų tinklas. Šụ valdų ir sodybų raida nuejjo sudètingą vystymosi procesą, ne kartą keitèsi savininkai. Statyboje ir planavime persipynė vietos tradicijos ir naujos tendencijos (barokas, klasicizmas, istorizmas, fachverkas). Nemaža dalis jų per XX a. antroje pusėje vykusius procesus sunyko ar visiškai išnyko nuo žemės paviršiaus, tačiau liko kaip archeologijos pažinimo šaltinis. Vienas tokių dvarų, atspindèjusių šias tendencijas, buvo Lieporų dvaras (buv. Upytės paviete, dab. Joniškio r. sav.), kuris iki 1583/86 m. priklausęs Livonijos ordinui, vèliau Kuršo ir Žiemgalos Kunigaikštystei po Livonijos karo perèjo Lietuvos Didžiajai Kunigaikštystei. Kurị laiką dvaras nuo 1539 m. valdytas vietos kilmingujų Druvių, o XIX a. tapo vokiečių baronų Grothusų atšakos rezidencija ir pradètas vadinti Grothusu Lieporais. 


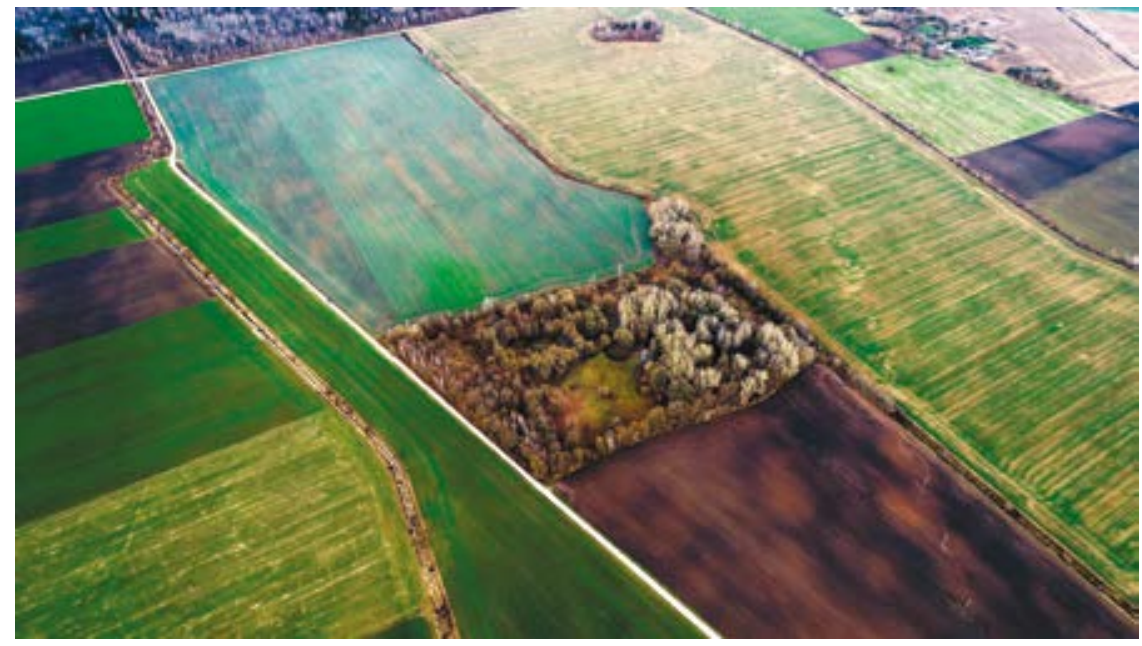

1.

Buv. Lieporų dvaro sodyba iš pietvakarių, 2020,

Former Lieporai manor from the south-west Ričardo Norkaus nuotrauka

Lietuvoje stebime augantị susidomėjimą dvarais, nemažai jų valstybės ir privačiomis lèšomis atkurta ir pritaikyta viešosioms reikmėms. Lietuvos Žiemgaloje, taip pat ir Joniškio krašte, aplinkybės susiklostė taip, kad nuo XVII a. nemažai privačių dvarų tapo iš gretimos Kuršo ir Žiemgalos Kunigaikštystės kilusių vokiečių kilmingujų nuosavybe. Tokiu būdu ilgam Joniškio krašte šaknis įleido baronai Trankvitcai (von Trankwitz), Bryginai (von der Brüggen), Landsbergiai (von Landsberg), Tyzenhauzai (von Tiesenhausen), Frankai (von Pfeilitzer gen. Franck), Grothusai (von Grotthuss), Goesai (von Goes), Vigantai (von Hohenastenberg gen. Wigandt), grafai Keizerlingai (Keyserlingk) bei kiti, jie suvaidino tam tikrą vaidmenị krašto ūkio, kultūros ir švietimo raidoje. Kai kurioms dvarų sodyboms su parkais pasisekė geriau - buvo išsaugoti, atkurti (Jakiškiai, Jurdaičiai, Žagarè, Žagariškiai-Raudondvaris), kitoms - istorijos tėkmė nebuvo tokia palanki. Kažkada buvę Žiemgalos lygumos kraštovaizdžio puošmenomis (Malgūžè, Lieporai I ir II) XX a. sunyko ir jų vietas mena likę sodybų fragmentai su ošiančiais parkais. Kiti laukia savo atgimimo - Medvilioniai, Daunorava, Paudruvè. 
Šį kartą pakalbėsime apie kitą nemažiau įdomių istorijų slepianti buvusį Lieporų dvarą (Kriukų sen., Mygūnai I). XIX a. perstatyta dvaro sodyba su mediniu ponų namu (su ant sienų kamabariuose kabejjusiais protèvių portretais), moliniais, fachverkiniais, mediniais gyvenamaisiais ir ūkiniais pastatais, sodu, kūdromis, parku ịnešè tam tikrą atspalvị ị monotonišką Žiemgalos lygumos kraštovaizdį. Jo savininkai baronai Grothusai buvo sukaupę senienų rinkinį, dalyvavo Mintaujoje (Jelgava) ịsikūrusioje Kuršo literatūros ir dailės draugijos veikoje. Dabar senają Lieporų dvaro sodybą mena tik sumiškėjęs sklypas su išlikusiais buvusio parko želdiniais [1 il.], ją puoselèja naujieji savininkai ūkininkai Tomas ir Sandra Rudžiai.

Šaltinių (XVI-XVIII a. Upytės pavieto žemės ir pilies, Raseinių (Žemaičių) pilies teismo ir Joniškio magdeburginio teismo knygos, Upytės pavieto 1775, $1790 \mathrm{~m}$. padūmès mokesčiu tarifai, kiti XIX a. dokumentai ir kartografinė medžiaga - LVIA, XVII-XVIII a. baronų Frankų (von Pfeilitzer gen. Franck) dokumentai - LVVA, 1922 m. žemės reformos dokumentai, kartografinė medžiaga - LCVA, žr. nuorodas žemiau $)^{1}$ ir literatūros apie Lieporų (vok. Leeparn, Leparn) dvarus, lyginant su Daunoravos, yra nepalyginamai mažiau. Geriau išliko ikonografinè medžiaga (apie 1910-1920 m. fotografavo paveldètojas Johanas), kuri saugoma sūnaus Michaelio Aleksandro Grothuso (Michael Alexander von Grotthuss) šeimos archyve. Tyrimui vertingos 1885-1908 m. dvaro įkeitimo Vilniaus valstybės dvarininkų žemès bankui bylos, vienoje iš ju yra $1885 \mathrm{~m}$. valdos planas ir $1894 \mathrm{~m}$. išsamus nuomos kainų, kumečiu (landsknechtai, kilę iš Kuršo ir vietiniai) samdos papročių ir užmokesčio, valdos, trobesių, žemės ūkio naudmenų, gyvulių ir jų realizacijos (grūdai - į Bauskę, Mintaują, Rygą, pieną supirkinèjo dvare gyvenęs žydas), miško, pajamų ir išlaidų, inventoriaus, valdymo, palivarkų nuomos sąlygų bei kt. aprašymas ${ }^{2}$, kurị būtų verta paskelbti atskira publikacija. Reikšmingi dvare gimusio Aleksandro Grothuso (Alexander (Lex) Julius Otto von Grotthuss, 1855-1933, savininko Aleksandro sūnus $\downarrow)^{3}$

1 Tyrime dèl covid-19 pandemijos trukdžių nepanaudoti XVI a. pabaigos - XVIII a. rašytiniai šaltiniai, saugomi Lietuvos mokslų akademijos Vrublevskių bibliotekoje (buvęs Šiaulių „Aušros“ muziejaus rinkinys, f. 37, pavieniai dokumentai tarp in. numerių b. A-6706-7063).

Už konsultacijas rengiant šị straipsnị autorius dèkingas architektūros istorikei dr. Dalei Puodžiukienei, istorikui dr. Jonui Drungilui.

2 Дело о выдаче ссуды барону Гротус Ф. А. в залог им. Лепары Шавельского у. Ковенской губ., 1885-1894, in: Lietuvos valstybės istorijos archyvas (toliau - LVIA), f. 542, ap. 1, b. 262, 1. 1-8, 28-39v.

3 [Grotthuss Alexander], Erinnerungen aus der Hand von Alexander Julius Otto Baron v. Grotthuss (*Leeparn 16.11.1855 †Pokroy 21.10.1933). Endbearbeitung durch Michael Alexander Baron v. Grotthuss, 2008 [mašinraštis]. 
ir dvaro prievaizdo marčios, rašytojos Melitos Vanagos (1905-1997) atsiminimai. Apie dvarą ir jo savininkus glaustai rašè Percy von Schroederis ${ }^{4}$, Kazys Misius ${ }^{5}$, Aleksandras Šimoliūnas ${ }^{6}$, Walteris von Hueckas sudarè baronu Grothusu genealogiją ${ }^{7}$, apie 1717-1777 m. samdinius valstiečiu ūkiuose rašè Mečislovas Jučas ${ }^{8}$, apie barono Frydricho Grothuso (Daniel Heinrich Theodor Friedrich von Grotthuss, 1851-1918) surinktus archeologinius radinius iš Lieporų kapinyno - šių eilučių autorius9. Šiame straipsnyje taikant šaltinių ir literatūros analizès, genealogini, aprašomajji metodus nagrinėjama buvusio žiemgalių administracinio junginio - apygardos transformacija ị lietuvišką Lieporų lauką, dvaro įkūrimo problema ir pirmieji savininkai XVI a. bajorai Druvès (Druvos), vientisos dvaro valdos susiformavimas XVIII a., jos dydis ir galiausiai baronų Grothusų valdymo laikais XIX a. susiformavusi dvaro sodybos struktūra, pateikiami palikuonio Aleksandro Grothuso ir rašytojos Melitos Vanagos atsiminimai apie dvarą.

\section{Dvaro pradžia ir bajorai Druvès}

Apgyvendinimo raida, kartu ir dvaru atsiradimas bei jų istorija Livonijos ir Lietuvos Didžiosios Kunigaikštystès (toliau - LDK) pasienyje kol kas nèra išsamiau tyrinèti. Čia jau pasibaigus intensyvioms kovoms, po Žalgirio 1410 m. ir Pabaisko 1435 m. mūšių, XV a. viduryje pastačius Bauskès pili, prasidejjo intensyvūs teritorijos kolonizacijos procesai. Intensyvejjant miškų kirtimui, tankejjant gyvenviečiu tinklui, atsirado poreikis sureguliuoti sieną $(1426,1473,1529,1541,1545,1582,1583-1586,1587)$. Tuo pačiu metu, XV a., Livonijos ordinas Žiemgaloje pradejjo dalyti būsimų dvarų valdas vasalams (pvz., magistras skyrè didelį feodą Hinrichui Fogelerui ir Arntui Vindhofelui $1457 \mathrm{~m} .{ }^{10}$ ), o Lietuvos pusejje dvarai steigiami nuo

4 Percy Schroeders, Nachrichten über Kurländer in Litauen, München: Kurländische Ritterschaft, 1984, p. 55.

5 Kazys Misius, „Vietovès“, in: Joniškio kraštas, Kaunas: Žiemgalos leidykla, 2011, p. 82-83.

6 Aleksandras Šimoliūnas, „Iš Joniškio krašto dvarų istorijos. Lieporų dvaras“, in: Žemygala, 2010, Nr. 1 (9) - 2 (10), p. 34-39.

7 Genealogisches Handbuch der Freiherrlichen Häuser, Hauptbearbeiter: Walter v. Hueck, Bd. VI: Stammfolge des Geschlechts der Freiherren v. Grotthuß, Limburg a. d. Lahn: C. A. Starke Verlag, 1966, p. 210-216.

8 Mečislovas Jučas, Baudžiavos irimas Lietuvoje, Vilnius: Mintis, 1972, p. 160, lent. 56.

9 Ernestas Vasiliauskas, „Lieporu (Joniškio r.) kapinyno radiniai (VI-XI a.)“, in: Lietuvos archeologija, Vilnius, 2007, t. 30, p. 213-228; Idem, „Grafų Keyserlingkų ir kitų Lietuvos dvarininkų archeologiniai rinkiniai Kuršo provincijos muziejuje“, in: Archaeologia Lituana, Vilnius, 2015, t. 16, p. 102-136.

10 Imants Lancmanis, Rundāles pils, Rundāle: Rundāles pils, 2007, p. 3. 
XV a. pabaigos - XVI amžiaus. Apie apgyvendinimo procesų mastus byloja faktas, kad Ordinas 1445-1447 m. Bauskès pilies statybai (1443-1451) iš Naugardo žemės į dabartines Latvijos Brunavos, Ceraukstès, Gailyšų, Islycès, Vecsaulès, Skaistkalnès, teritorijoje tarp Žeimelio ir Saločių Lietuvoje ir kitas apylinkes atkèlè apie 3000 belaisvių - vodų ${ }^{11}$. Ju palikuoniai ilgainiui XVII-XIX a. pradèti vadinti krievingais. Ūkininkų pavardės Krieviṇi (Krewin, Kriewiń, Kriewini, Krewinie (lenk.), Krewing (vok.), Криевинъ, Кревинъ (rus.), Kreewing (lat.)), samdiniai pavarde Igaunis (liet. Estas, Lyberių k. (vok. Libeschen)) bei kitos fiksuotos ir Grothusų valdyto Pograničos dvaro Rūdynès kaime (1811-1850 m. revizijose) $)^{12}$, o gretimo Brunoviškių dvaro valdoje žinomas Krievgalių kaimas (iki $1921 \mathrm{~m}$. priklausė Lietuvai, dab. Gailyšų apyl.). Matyt, seniausia užfiksuota šio tyrimo objekto Lieporu dvaro pavadinimo - Żybort mü̈ża/mö̈ża (1539, 1586) finougriška forma (dvaras - muyza, moyze, tarm. muižè, lyv. moize, mois, est. mõis, krieviniu moise, mõiza) yra susijusi su minètais kolonizacijos procesais.

Lieporų laukas Upytės paviete rašytiniuose šaltiniuose yra žinomas jau nuo XVI a. Ankstesnių duomenų (pvz., 1473, 1529, 1545 m. LDK ir Livonijos sienų nustatymo sutartyse) vietovè nèra minima. Šios apylinkès iki Kryžiaus karų pabaigos 1290 m. priklausė Rytų Žiemgalos - Upmalès žemei, tikètina, buvo viena jos sudètinių dalių - apygarda (jų bendruomenès nariai laidoti tyrinètuose VI-XIII a. Kriukų-Dvareliškių ir

11 Vodai - praktiškai išnykusi finų tauta, gimininga estams, savo tapatybę, kalbą, kostiumą, papročius išlaikė iki pat XIX a., vietos gyventojų vadinti krievingais (krieviniai, lat. krievingi, vok. Kreewin, Kreewing, išvertus ị lietuvių - ruseliai). Plačiau apie juos žr:: Beschreibung der Provinz Kurland: Nach Anleitung des unter Allerhöchsten Schutz Seiner Kaiserlichen Majestät von Einer freien ökonomischen Gesellschaft zu St. Petersburg im Jahr 1802 angefertigten Entwurfs, Hrsg. Keyserling P. von; Derschau Ernst von, Mitau: J. F. Steffenhagen und Sohn, 1805, p. 186, 188-190; Reise nach Livland und Kurland zur genauen Untersuchung der Reste der Liwen und Krewingen, von A. J. Sjögren, Weimar, 1847; Ferdinand Johann Wiedemann, Über die Nationalität und die Sprache der jetzt ausgestorbenen Kreewinen in Kurland, St.-Pétersbourg: Eggers in Komm, 1871; „Kreewini“, in: Konwersazijas wahrdniza, Rīga, 1908, t. 2, p. 124; „Krievini““, in: Latviešu konversācijas vārdnīca, Rīga: A. Gulbis, 1933, t. 9, p. 18339-18340; Ilga Jansone, „Krievin̄i un to atstātās pēdas Zemgalē“, in: Raksti, t. V: Starptautiskās zinātniskās konferences zinātniskie lasījumi Ģ. Eliasa Jelgavas vēstures un mākslas muzejā materiāli, Jelgava: G̦. Eliasa Jelgavas vēstures un mākslas muzejs, 2008, p. 47-57. Apie finų substratą pietinėje Žiemgaloje rašè ir Žeimelio kraštotyrininkas Juozas Šliavas (1930-1979), tačiau šių lingvistinių reliktų nesiejo su minètais krievingais, o su žymiai senesniais reiškiniais (Juozas Šliavas, Žiemgaliu pédsakais, Vilnius: Žiemgala, 1996, p. 21-22, 49-53). Matyt, visgi šiuos reliktus Lielupès baseine reiktų sieti su gerokai vèlesniais procesais - vodų atkeldinimu XV a. viduryje ị Rytų Žiemgalą.

12 Muižnieku dzimtu dokumenti. Grothusu dzimtas arhīvs. Dokumenti (revīzijas lapas, lūgums, kvīts) par dvēselu revīziju Pograničas muižā, 1811-1850, in: Latvijas valsts vēstures arhīvs (toliau - LVVA), f. 1100, ap. 6, b. 23, 1. 3v, 17, 31, 33, 47, 63, 77, 92, 108, 148. 
Lieporų kapinynuose). Ji pagal Lieporų upelị galëjo būti vadinama tuo pačiu - Lieporu vardu (XIII a. šaltiniuose šioje Upmalès dalyje minimos tik Plonès žemė su Šiurpès ir Guostagalio pilių apygardomis), taigi pavadinimo kilmė - hidroniminè. Ši Lieporų apygarda Livonijos ir LDK laikais XIVXVI a. virto lauku, kuriame ilgainiui susiformavo smulkesni ūkiniai-administraciniai vienetai - dvarai. Analogijas galima ižvelgti ir gretimoje $1254 \mathrm{~m}$. minimoje Plonės žemejje / apygardoje (ad terram, quae Plane dicitur), kur XVI a. Plonės upelio krantuose susiformavo atskiri - Didžiujų ir Baltuju Plonėnų dvarai su Plonėnų miesteliu ir kalvinistų bažnyčia. Pastebėta, kad XV a. pabaigoje - XVI a. buvusių pietų Žiemgalos centrų vietose (ar visai greta jų) formavosi parapijų centrai - Pašvitinys, Žagarè, Pasvalys, Linkuva, Joniškis, Papilè, Kuršėnai ir kt., kurie iki pat XIX a. vidurio atliko tam tikras administracines funkcijas. Lieporų apygardos / lauko atveju XVIII a. Kriukuose iškilo filijinė bažnytėlè (minima 1725 m.), priklausiusi didelei Pašvitinio parapijai, kuri $1803 \mathrm{~m}$. pertvarkyta ị atskirą parapiją ${ }^{13}$.

Šio lauko ribas, remiantis Upytės pilies ir žemės teismų 15841615 m. knygomis, galima apibrèžti taip: dažnai minimas orientyras - Lieporo upelis (t. y. abu aukštupio ir vidurupio krantai), prie Inflantų [Kuršo] sienos $(1586,1595,1614)$, ribos ties Švitinio upeliu (1586) bei tarp Lieporo ir Šešèvės upelių (1588), vietovardžiai - Sodakadruvė (1586, Содакадруве), Mikiškiai (1614, Микишки), Žemaičių vyskupo Merkelio Giedraičio pavaldinys pirklys Paulius Kriukis, gyvenęs Lieporų lauke, Surviliškių kieme / kaime, prie Šešèvės upelio (1586, въ поль Лепарахь, надъ р. Шешевою, двора Сурвилишскаго), iškirstas miškas (1589), Žemaičių vyskupui Merkeliui Giedraičiui priklausę Viškūnų (Вишкуны) ir Kriukų (Круки) kaimai su 33 valakais žemès, kurie keliasdešimčiai metų buvę prijungti prie Druvių Skakų (Скоки) arba Lieporų dvaro (1614), Lieporų bajorkaimio (?) sodybos / namai $(1588,1612)^{14}$. Kartografavus šiuos toponimus matyti, kad Lieporų laukas tarp Šešèvès ir Švitinio upių galèjo apimti apie 5705 ha plotą.

13 Liudas Jovaiša, „Kriukų Šv. Lauryno bažnyčios istorija“, in: Lietuvos sakraline daile, t. II: Šiauliu vyskupija, d. 1: Joniškio dekanatas, kn. 2: Juodeikiai-Rudiškiai, Vilnius: Lietuvos kultūros tyrimų institutas, 2012, p. 155-156.

14 Описъ документовъ Виленскаго центрального архива древнихъ актовыхъ книгъ, Вильна: Типографія Бр Д. и Х. Яловцеръ, 1909, t. VII, p. 152 / Nr. 878, p. 76 / Nr. 462, p. 135 / Nr. 794, p. 137 / Nr. 807, p. 171 / Nr. 973; Описъ документовъ Виленского центрального архива древнихъ актовыхъ книгъ, Вильна: Типографія Бр Д. и Х. Яловиеръ, 1912, t. VIII, p. 26 / Nr. 200, p. 361-362 / Nr. 295-296, p. 147 / Nr. 1098, p. 242 / Nr. 616, p. 355 / Nr. 267, p. 459 / Nr. 301-304, p. 114 / Nr. 114, p. 61 / Nr. 457458 , p. 61 / Nr. 460. 


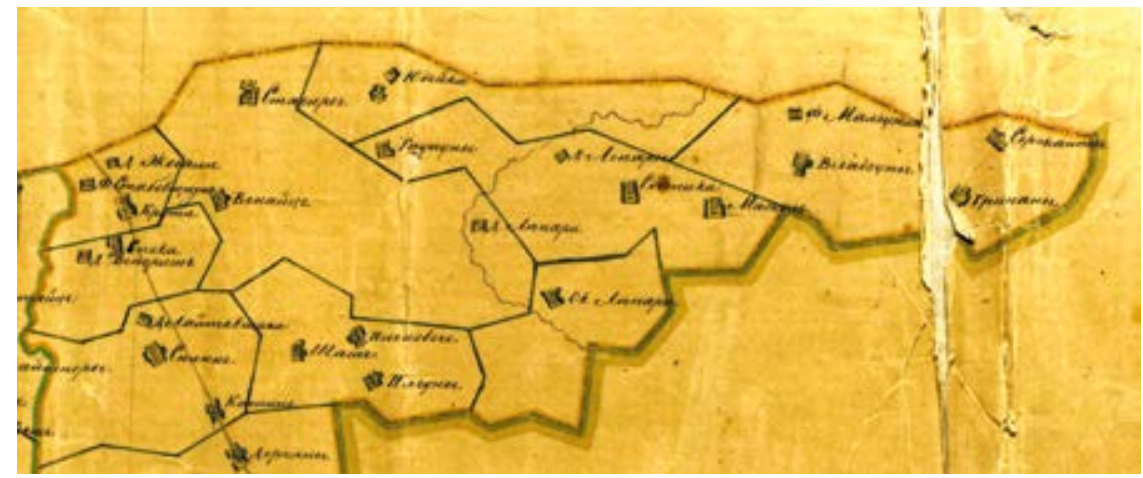

2.

Buv. Šiaulių apskr. Pašvitinio parapijos dvarų valdos teritorija, 1583-1586 m. perèjusi LDK iš Livonijos / Kuršo ir Žiemgalos Kunigaikštystès, scheminio žemèlapio fragmentas, 1843, LVIA, f. 526, ap. 7, b. 5444

\begin{abstract}
Former manor properties of the Pašvitinys parish of the Šiauliai County - the territory transferred from Livonia / the Duchy of Courland and Semigallia to the Grand Duchy of Lithuania in 1583/86. Detail of a blueprint map. 1843
\end{abstract}

Ilgainiui XVI-XIX a. šiame Lieporų lauke susiformavo atskiri 7 vienetai (dvarai), išsaugoję senajji pavadinimą: privatūs Grothusų Lieporų ir Brašo (pagal paskutinius savininkus), Albertiškių (Albrychtowo alias Lepar), Medvilioniu (XVII a. - 1769 m. dar vadintas Lieporu - Medwiłany alias Lepary), Lieporų bajorkaimis (su 10-11 dūmų) ir, tikètina, vèliau senojo pavadinimo neišsaugoję Juodeikių, Vengriškių, Žemaičių vyskupo Kriukų dvarai. Lieporu dvaro ne kartą keitėsi savininkai ir pavadinimai [2 il.]. Seniausi žinomi dvaro, vadinto Žybartų ( $\dot{Z} y$ bort mö̈ża alias Lepary w okolicy Leparach), savininkai - Druvès (Druvos, lenk. Druwa, Druw, Druf, Druff, vok. Druwe, Traube) minimi $1653 \mathrm{~m}$. Upytès teismo knygoje, kur nurodoma, kad Livonijos ordino magistras Hermanas Briugenëjus (Hermann von Bruggenei, gen. Hasenkamp, 1535-1549) 1539 m. privilegija feodo teise dvarą, nuo seno vadintą Żybort Muÿza, Kurše [Livonijoje] ir Lietuvos pasienyje, už sąžiningą tarnybą paskyrẻ Jonui Druvei. Pagal karaliaus Stepono Batoro 1583-1586 m. sudarytos komisijos Abiejų Tautų Respublikos ir Kuršo sienai nustatyti atliktą korekciją dvaro valda iš Livonijos perèjo LDK ir buvo patvirtinta su visomis paveldèjimo teisèmis Kuršo riteriui Jodokui Druwei $^{15}$. Še faktai byloja tai, kad Lieporai po 1529 m. LDK ir Livonijos

15 Aktykacia listu dzielczego ich mosci panom Druwom służącego, 175707 05, in: LVIA, f. 285, ap. 1, b. 58 (SA-14555), l. 138-139; Описъ документовъ, t. VIII, p. 171, Nr. 973; Grzegorz Błaszczyk, Herbarz szlachty Żmudzkiej, t. I: $A-F$, Warszawa: DIG, 2015, p. 585. 
sienos korekcijos dar priklausė Livonijai (kitaip vargu ar magistras galèjo skirti valdą savo vasalui) ir Lietuvai perejo pasibaigus Livonijos karui, po 1583-1586 m. atlikto sienos patikslinimo (šaltiniuose dvaro savininkas Druvė įvardijamas kaip Livonijos / Kuršo pavaldinys). Pagal 1545 m. Livonijos ir LDK sienu aprašymą matyti, kad nagrinėjama teritorija priklausė Mintaujos komtūrijai (riba tarp jos ir Bauskès èjo Pelaniškių (Kalnuočių) piliakalniu (montem Pillaten)? $)^{16}$. Kita Kuršo ir Žiemgalos Kunigaikštystès teritorija analogiškai perejjusi LDK buvo Dytricho Grothuso (Dietrich von Grotthuss) Rundalès valdos pietinè dalis su vèlesniais Žeimelio, Pažeimelès, Kratošino ir Malgūžių dvarais (apie ši yra parengtas tyrimas). Apie tai byloja fragmentiškai išlikęs 1585 m. sienos aprašymas ${ }^{17}$. Laikotarpis po Livonijos karo sienų korekcijos menkai dokumentuotas, o dvarų tyrimai padeda užpildyti šias spragas.

Praktika, kai Ordinas pradėjo skirstyti feodus savo vasalams - pirmiausia vietiniams kilmingiesiems (kuršių, lyvių, Latgaloje, Sėloje, Žiemgaloje), fiksuojama jau nuo XIII a. pabaigos iki pat XVI amžiaus. Tokiu būdu magistras Finkè (Heinrich Vinke von Overberg, 1438-1450) 1444 m. skyrè feodą Pretsui Kerchshui, jo broliui Vetsenui ir posūniui Jokūbui bei jų palikuoniams Duobelès miestelyje, vietiniai vasalai žinomi ir prie Mežuotnès bei Bauskės. Jų skyrimą skatino keletas aplinkybių - nuolatiniai karai su kaimynais (XV a. viduryje su rusų Naugardo, XV-XVI a. sandūroje su Maskvos didžiuoju kunigaikščiu Ivanu III), be to, vietinius kilminguosius laikè lojalesniais nei vokiečius. Vietinių kilmingujų valdyti feodai dominavo iki pat XIV a., o XV a. pradeda dominuoti vokiečių kilmingujų. Vietinių feodų, palyginus su vokiečių, skaičius mažėjo dèl ịvairių priežasčių: vietiniai nebuvo laikyti pakankamai kilmingais, nemaža dalis suvokietėjo (kuršiai von Gayl), susiliejo per mišrias santuokas, nemažai giminių išmirè ar žuvo karuose ${ }^{18}$. Šis modelis taikytinas ir minėtiems Druvėms bei kitoms krašto giminėms.

Druvės dar valdė ir Vengriškių palivarką, kurị su trobesiais ir klojimu Jurgis, Kristupas ir Zigmantas 1653 m. lapkričio 10 d. perleido broliui Aleksandrui, o jauniausiam Zigmantui atiteko Migališkiai, Jurgiui ir

16 Tomas Čelkis, Darius Antanavičius, „1545 metų Livonijos ir Lietuvos Didžiosios Kunigaikštystès sienos patikrinimas (Livonijos pareigūnų ataskaita)“, in: Lietuvos istorijos studijos, Vilnius: Vilniaus universiteto leidykla, 2011, Nr. 27, p. 175.

17 XVI amžiaus Lietuvos inventoriai, sud. Konstantinas Jablonskis, Kaunas: Menas, 1934, t. I, p. 265-274.

18 Indriķis Šterns, Latvijas vēsture. 1290-1500, Rīga: Daugava, 1997, p. 469-473, 478, 480, 501. 
viduriniajam Kristupui - Žybartų dvaras su namu, trobesiais, kluoniena, ariama ir neariama žeme, šienaujamomis pievomis ir miškais, pavaldiniais ${ }^{19}$. Bajorų Druvių kilmė (herbas Wczele) kol kas nenustatyta - ịprastai tyrèjai juos kildina iš Livonijos ${ }^{20}$. Pagal pavardès etimologiją (latv. druva-baimè $\dot{e}^{21}$, laukas, dirva ${ }^{22}$ ) galima manyti, kad tai sena Žiemgalos krašto giminè, panašiai kaip bajorai Leparskiai, Vilkickai, Plonianskiai bei kiti. Nustatytos 8 Druvių kartos: giminès pradininku nuo $1539 \mathrm{~m}$. laikomas minètas Jonas Druvė (I), jis turèjo sūnų Jodoką [Justą] (II) ir anūką Otoną Johaną (III), o šis turèjo 4 sūnus - Jurgị, Aleksandrą, Kristupą, Zigmantą (IV). Jurgis ir Aleksandras minimi 1655 m. „tvano“ metu pasirašę uniją su Švedija. Jurgis turèjo sūnų Joną, o Aleksandras - Baltazarą ir Kristupą (V). Jonas turèjo sūnus Igną, Tadą ir Petrą (VI), o Petras - Antaną, Juozapą ir Vincentą (VII), vėlesniajai kartai atstovavo Juozapas Antano ir Mykolas Vincento (VIII) ${ }^{23}$. Kaip byloja Upytès pilies teismo 1584-1615 m. knygose surašyti 16140301 testamentas ir 161303 30, 161402 04, 16140307 garantiniai raštai, jie giminiavosi su kitomis įtakingomis Kuršo giminėmis: Justas Drufa-Žybortas, be šio dvaro, valdęs dar ir Aschhofo dvarą (nelokalizuotas) prie Salgalès upės, buvo vedęs Dorotėją Sacken (Otono dukra, jai užrašyta 1000 talerių ir po mirties dalis nuosavybės), jų dukra Dorotėja buvo ištekinta už Jono Bistramo ir „pagal vokiečių žemių paprotị“ pažadètas kraitis - be rūbų, kitų daiktų, kurie duodami iš meilès vaikams, dar pažadèta 1200 auksinų (kurių išmokèta 400, o už likusius tam pačiam Bistramui užstatyta Lieporų dvaro dalis su pavaldiniais, kitame dokumente dèl likusios skolos dalies išmokèjimo patikslinta, kad 100 lenkiškų auksinų buvo verti 40 kapų lietuviškų grašių) ${ }^{24} .1619$ m. minimas ir Johano Otono (iš Lieporų Lietuvoje) bei jo žmonos (namų ponios) (?) Adelheid Schelkens sandèris dèl 2 valstiečių ūkių pardavimo ${ }^{25}$. Bajorai Druvès Lieporų dvarą (1661-1685/1717 m. dar vadintas

19 Op. cit., in: LVIA, f. 285, ap. 1, b. 58 (SA-14555), 1. 138v-139.

20 Rita Regina Trimonienė, „Svetimšalių ir svetimtaučių bajorų imigracija į Žemaitiją XVI a. antrojoje pusėje - XVII a. pirmojoje pusejje: imigracijos kultūriniai veiksniai ir įtakos žemaičių visuomenei“, in: Rytu Europos kultūra migracijos kontekste: tarpdalykiniai tyrimai, Vilnius: Versus aureus, 2007, p. 499; Grzegorz Błaszczyk, op. cit., p. 585.

21 Drūve, drūvéties - bijoti, būti neužtikrintam, liūdnam, baugštus (Janīna Kursīte, Neakadēmiskā latviešu valodas vārdnīca jeb novadu vārdene, Rīga: Madris, 2007, p. 82).

22 Lietuviu pavardžiu žodynas, t. 2: L-Ž, ats. red. A. Vanagas, Vilnius: Mokslas, 1989.

23 Grzegorz Błaszczyk, op. cit., p. 586.

24 Описъ документовъ, t. VIII, p. 361-362 / Nr. 295-297, p. 480 / Nr. 471, p. 471 / Nr. 394.

25 Kurländische Güter-Chroniken. Neue Folge. Kautzmünde, Ruhenthal, Schwitten, Mitau: E. Behre's Commissions-Verlag, 1899, Lies. I, p. 78. 
Karklynės (Karklien) vardu) valdè 1539-1666/1676 m., po jų - baronai Frankai 1666/1676-1826/1834 m. ${ }^{26}$, laikinai Tyzenhauzai - $1763-1773 \mathrm{~m} \cdot{ }^{27}$, galiausiai tarp 1826/1834 ${ }^{28}-1940$ m. Grothusai.

Kaip matyti iš $1644 \mathrm{~m}$. dokumento, Druvès valdè ir kitą Lieporu dvarą (vėliau žinomą Brašo Lieporų) su Bikaičių kaimu ${ }^{29} 1725$ m. Pašvitinio parapijos ribų aprašyme minimi našlei Druvienei priklausę Mišeikių kaimas, Pavirčiuvės dvaras, Vengriškių dvaras, <...> Butkūnų ir nenustatyti kaimai, Drevininkų užusienis (wioska Miszeykie Pani Druwowey, dwor Powirczuw Pani Druwowey, dwor Wegryszki takze tey pani Druwowey, chlop Jasulis ieden, wioska Ržele, wioska Stulbele, wioska Butkuny, chlop Drawinikas pni Druwowey), pono Bolšvingo - Bikaičių ir Juodeikių kaimai, dvaras (wioska Beykaycie, wioska Judeykie, dwor Pa Bolswinga), pono Franko - Gailiūnų kaimas Kuršo pasienyje, Sodininkų kaimas (wioska Gayluny Pograniczu Kurlandskim, wioska Sodyniki Pa Franka) $)^{30}$.

\section{Lieporų Grothusų atšaka}

Baronai Grothusai - sena ir įtakinga Livonijos ordino, Kuršo ir Žiemgalos Kunigaikštystès giminè, susijusi su kitomis krašto giminėmis Keizerlingais, Goesais, Frankais ir kt. Giminès pradininku laikomas Otas Grothusas (Otto von Grotthuss, †1527; I), kuris 1505 m. įsigijo didelę Rundalès valdą, jo sūnūs pasidalijo tèvo palikimą ir tokiu būdu susiformavo baronų Grothusų giminès 3 atšakos: Rundalę paveldejo vyriausiasis sūnus Otas (Otto von Grotthuss, †1577), Svitenę - vidurinysis sūnus Tomas,

26 1666-1680 m. dvaro savininku minimas Kuršo kancleris Evaldas Frankas (Ewald von Pfeilitzer gen. Franck) ir jo žmona Barbora Margarita iš Švarcų (Schwarz) (̌̌r. Muižnieku dzimtu dokumenti. Pfeilitceru-Franku dzimta. Dokumenti (ziņojumi, testamenti, līgumi u.c.) par nekustamā ipašuma mantošanu, 1626.-1880, in: LVVA, f. 1100, ap. 13, b. 1085, 1. 119v; Muižnieku dzimtu dokumenti. Pfeilitceru-Franku dzimta. Dokumenti (spriedums, protests, protokoli) par dzimtas loecklu kārtotajiem juridiskajiem jautājumiem. 1666.-1810, in: LVVA, f. 1100, ap. 13, b. 1101, 1. 3, 7, 11-12, 19). Genealoginèse lentelèse aptinkami XVII a. gyvenę 2 Evaldai: 1) Mikalojaus (Nicolaus) ir Anos (Anna von Behr) (Wisseln, Pūrès (Puhren), Sèmès (Sehmen, lat. Sēme), Culven dvarai), 2) Klauso (Claus) (Pūrès (Puhren) dvaras) sūnūs, abiem atvejais Pūrès (vok. Puhren) dvaro savininkas (žr. Kurzemes bruṇniecības arhīvs (1656-1938). Franck-Pfeilitzer. 19. gs., in: LVVA, f. 640, ap. 3, b. 97, 1. 2, Tab. I; Materiāli par personām Rīgā un Baltijas provincēs. Pfeilitzer, 1748.-1878, in: LVVA, f. 4011, ap. 1, b. 4278).

27 Op. cit., in: LVVA, f. 1100, ap. 13, b. 1085, 1. 119-120.

28 Vieni šaltiniai nurodo, kad Lieporų dvarą Grothusai ịsigijo apie $1815 \mathrm{~m}$. ([Grotthuss Alexander], op. cit.; Aleksandras Šimoliūnas, op. cit., p. 34), kiti - 1834 m. (Kazys Misius, op. cit., p. 83).

29 Actt inwentarza od jego mosci pana Druwa straznika Xięstwa Zmuydskiego jego mosci Panu Treydanowi podczaszemu pinskiemu z pani małzące jej mości słuzącego, 1644-1645/1694, in: LVIA, SA-39, 1. 405-406v.

30 Pašvitinio bažnyčios inventorius, 172510 16, in: LVIA, f. 1671, ap. 4, b. 424, 1. 8-8v. 


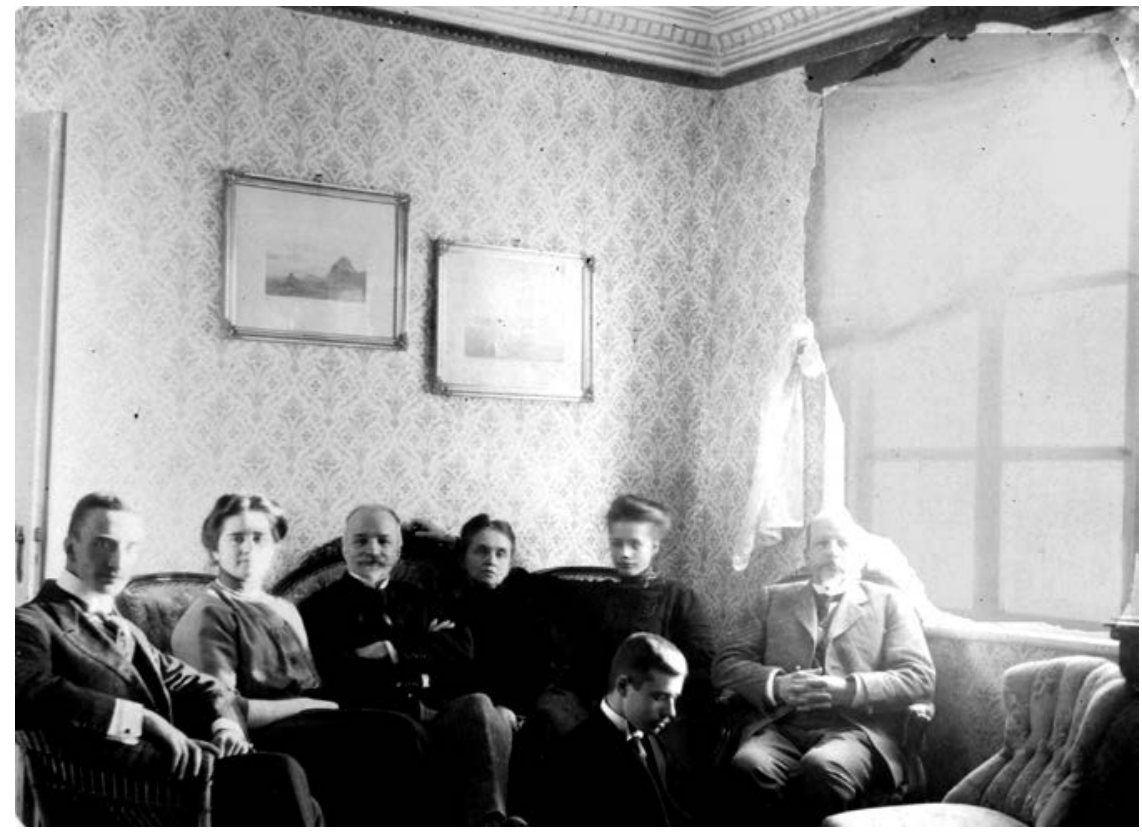

3.

Frydricho Grothuso šeima svečiuose pas brolị Harị (Otto Heinrich (Harry)) Mintaujos bute apie $1909 \mathrm{~m}$. Iš kairès sèdi: Leo (Leopold (Leo) Birckenstaedt, 1869-1947, žentas, Almos vyras), Alma (Alma Wilhelmine Marie, 1879-1923, dukra iš pirmos santuokos), Frydrichas (Daniel Heinrich Theodor Friedrich, 1851-1918, tèvas), Marija (Marie geb. von Behr, 1856-1935, antroji žmona - motina), Marija (Alma Ina Marie (Mary), 1894-1963, dukra), Johanas (Hansas) (Alexander Arthur Ernst Johann (Hans), 1891-1959, tupi, sūnus), Aleksandras (Alexander (Lex) Julius Otto, 1855-1933, brolis)
Friedrich von Grotthuss's family visiting his brother Harry (Otto Heinrich) in his flat in Mitau (Jelgava) ca. 1909. Sitting from the left: Leopold (Leo) Birckenstaedt (1869-1947, son-in-law, Alma's husband), Alma Wilhelmine Marie (1879-1923, daughter from the first marriage), Daniel Heinrich Theodor Friedrich (1851-1918, father), Marie (geb. von Behr, 1856-1935, second wife-mother), Alma Ina Marie (Mary) (1894-1963, daughter), Alexander Arthur Ernst Johann (Hans) (1891-1959, squatting, son), Alexander (Lex) Julius Otto (1855-1933, brother)

Berstelę - jauniausieji Hermanas (II) ir Detlofas (tolesnis jo likimas nėra žinomas). Berstelès atšakos Hermanas susilaukè sūnaus Hildebrando (III), o šis - sūnaus, pavadinto senelio Hermano vardu $(\dagger 1638 ; \text { IV })^{31}$. Giminei įsigyjant atskirus dvarus, formavosi atskiros atšakos. Tokiu būdu Bauskès seniūnas Otas Johanas (Otto Johann II, 1701-1742, iš Berstelès atšakos, VIII kartos Otto palikuonis) laikomas Brunoviškių atšakos pradininku (nuo 1730 m. valdè Brunoviškių ir Kamardès (iki 1921 m. abu priklausė Lietuvai, dab. Latvija)). İdomu, kad Kamardès atšakos pradininkas jo sūnus 
Kristupas Ernestas (Christoph Ernst, 1736-1800; IX; taip pat Kamardès (vok. Komoddern) ir Brunoviškių (vok. Brunnowischek, Brunnowiszek) dvarų savininkas) $1762 \mathrm{~m}$. Duobelèje vedè tolimą giminaitę - Aną Grothus (Anna Alexandrina Juliana Lovisa von Grotthuss, 1744-1800), Gedučiu dvaro savininko, kompozitoriaus Evaldo (Ewald Dietrich, 1751-1786, Rundalès atšakos) seserị. Priminsime, kad Evaldas ị Lietuvą atsivežè pirmajji klavesiną, buvo garsaus Lietuvos ir Kuršo mokslininko Teodoro (Theodor, 1785-1822) tèvas. Tokiu būdu tiesioginiai kraujo giminystès ryšiai Lieporu Grothusus sieja su garsaus mokslininko gimine. Jo sūnus Frydrichas (Otto Ewald Friedrich, 1774-1848; X) tarp 1826-1834 m. įsigijo Lieporų dvarą, ịrengė šeimos pagrindinę rezidenciją ir yra laikomas šios atšakos pradininku. Nuo 1866 m. dvaras priklausè šio sūnui Aleksandrui (Carl Alexander, 1813-1875; XI), o nuo 1878 m. - anūkui Frydrichui (Daniel Heinrich Theodor Friedrich, 1851-1918; XII $)^{32}$ ir galiausiai 1918-1941 m. - proanūkiui Johanui (Hansui) (Alexander Arthur Ernst Johann (Hans), 1891-1959; XIII $)^{33}$ [3 il.]. Nuo XIX a. Lieporų dvaras tam, kad atskirtų nuo kitų Lieporų dvarų (Brašo (Brasch-Leeparn) ir bajorkaimio 10 valdų), pradètas vadinti Grothusų Lieporu (Grotthuss-Leeparn, госп. дв. Лепары Гротуса).

\section{Valda XVIII-XIX a.}

Nagrinėjamoje teritorijoje XVI a. pabaigoje pastebima specifinė smulkioji - žemèvalda. 1585-1595 m. dar minimas Lieporų laukas (pasak Juozo Jurginio, XVI a. lauką reikia sieti su XIII-XIV a. laukais, tai - tarp mišku įsikūrusių žemdirbių sodybos su dirvomis ir pievomis, tarp kurių nematyti bajoriško tipo kiemų-kaimų 34 ; latviškas atitikmuo būtų pagasts, kurie žinomi nuo XIV a., buvo sudėtinè parapijos ar apygardos dalis, formavosi priešistorinių pilių apygardų pagrindu, sudarė vienas ar keletas kaimų, su savo teritorija ir ribomis ${ }^{35}$ ), kiemai (dvarų, bajorkaimių ar kaimų ištakos (Livonijoje kaimas - ciems ịvardijamas kaip sudètinè pagasto dalis $\left.{ }^{36}\right)$ ) ir dvarai,

32 Muižnieku dzimtu dokumenti. Grothusu dzimtas arhīvs. Dzimtas genealogiskas tabulas par 16.-19. gs., in: LVVA, f. 1100, ap. 6, b. 36, 1. 4v, 6, 8, 13; Muižnieku dzimtu dokumenti. Grothusu dzimtas arhīvs. Dzimtas genealogiskas tabulas, 1570-1872, in: LVVA, f. 1100, ap. 6, b. 6, 1. 11; op. cit., in: LVIA, f. 542, ap. 1, b. 262, 1. 13; Genealogisches Handbuch der Freiherrlichen Häuser, p. 208-213; Percy Schroeders, op. cit., p. 18, 45-46, 55.

33 Aleksandras Šimoliūnas, op. cit., p. 34-36, 39; Kazys Misius, op. cit., p. 83.

34 Juozas Jurginis, Baudžiavos įsigalèjimas Lietuvoje, Vilnius: Valstybinè politinès ir mokslinès literatūros leidykla, 1962, p. 124, 166, 168.

35 Indrikis Šterns, op. cit., p. 519-523.

36 Ibid. 
namai su daugybe savininkų pavardžių. Pavyzdžiui, 1667 m. Lieporų lauke nurodyti 33 bajorai, iš jų 13 Leparskių pavarde, 8 bajorai turèjo valstiečių, iš viso 80 dūmų ${ }^{37}$. Analogijų galima ịžvelgti Livonijoje, kur latvių istorikas Indrikis Šternas, tyręs Vidžemės dvarų valdas 1412-1495 m., pastebėjo, kad, pagal turimus duomenis, jas ịprastai sudarė nuo 2-20 žagrių (t. y. 20200 ha), o Ordino vasalų feodai paprastai buvo dar mažesni (vos keletas valstiečių ūkių), o didesni (9-22 žagrių, 2 kaimų) - retos išimtys ${ }^{38}$. Lieporai vėlai, 1583-1586 m., perėjo LDK, tad čia pavėluotai buvo vykdoma valakų reforma. Tikriausiai sekant LDK pavyzdžiu, XVI a. pabaigoje - XVIII a. žemėvalda stambejo - formavosi dvarai su gatviniais kaimais, bajorkaimis (pasak J. Jurginio, žemininkai, turėję vos vieną kitą valstieti arba visai jų neturèję, savo žemių valakais nematavo ir ị kaimus nesikèlè, todèl jų sodyboms prigijo akalicu vardas ${ }^{39}$ ). Kuršo ir Žiemgalos Kunigaikštystès valstybiniame Sesavos dvare, pasienyje su LDK, visai greta Lieporų valdų, XVIXIX a. buvo laisvujų žemininkų (kioninių) Butkūnų kaimas (das Freidorf Butkuhnen oder Nowadneeken), o XIX a. ilgainiui jie perèjo į katalikybę ir sulietuvèjo (littausiche Freidorf) ${ }^{40}$.

1586 m. rugpjūčio $30 \mathrm{~d}$. skunde fiksuota seniausia užuomina apie dvaro sodybą prie Lieporo upelio: „dèl užmušimo tėvų jų Baltramiejaus ir Andriaus, tėvo jo Jono Druvės, ir apie išvarymą dabartinių palikuonių iš namų ir dvaro ir dèl užgrobimo žemių, abiejuose Lieporo upelio krantuose ir moižos pastatų tame sklype“ (о забытя отиовъ ихъ Балтромея $и$ Андрушка, отиа его Яна Друве, и о выгнанье иншыхъ продковъ ихъ з домовъ и оть маетностей и о забранье кгрунтовъ по обе стороне речьки Лепари и побудованбе мойжы на томъ кгрунте $)^{41} .16140301$ patikslinta, kad ji buvo prie Kuršo pasienio ${ }^{42}$.

Daugiau duomenų apie Lieporų dvaro valdą yra iš XVIII amžiaus. Antai 1717 m. Vilhelmas ir Elžbieta (geb. von Pfeilitzer gen. Franck) Sakenai (von Sacken) už 5000 muštinių talerių „geromis monetomis“43 perleido Kristupui Frankui (Christoph von Pfeilitzer gen. Franck) Lieporu ir

37 Kazys Misius, op. cit., p. 82.

38 Indrikisis Šterns, op. cit., p. 455-456, 503.

39 Juozas Jurginis, op. cit., p. 286.

40 Latvių istoriko Agrio Dzenio informacija. Sitzungsberichte der kurländischen Gesellschaft für Literatur und Kunst aus dem Jahre 1881, Mitau: J. F. Steffenhagen und Sohn, 1882, p. 61.

41 Описъ документовъ, t. VII, p. 152 / Nr. 878.

42 Описъ документовъ, t. VIII, p. 362 / Nr. 295.

43 T. y. aukštos prabos sidabro talerių monetomis (taleriai, 1/2 talerio ir 1/4 talerio). 
Karklynės (Mažujų Lieporų) palivarko (Majetnesa Lepary i do folwarku Karklinia alias Małe Lepary) pavaldinius. Inventoriuje Judiškių (Judyszki) kaime minimos 1 sodyba ir 5 tušti sklypai, Gaikoniuose (Gaykony) - 6 ir 7 tušti, Latvelių (Latwele) kaime -5 ir 6 tušti, Mažèlių - 3 ir 1 tušti ${ }^{44} .1741$ m. kitas Lieporų dvaras pagal savininką vadintas Anusevičių (Lepar alias Anusewicz), kuriam priklausė Andrešiūnų (Andruszuny), Mažèlių (Mazele), Andriejūnų (Andrejuny) kaimai. Dvaras 1699 m. priklausė Anusevičiams, 1720 m. - Kojelavičiams, o 1741 m. Johanas Frydrichas Medemas pardavè Kijevo vaivadystès sargybiniui Rafaeliui Pranciškui Landsbergiui $(\dagger 1754)^{45}$. $1763 \mathrm{~m}$. jis jau vadintas Albertiškių-Albrechtavo vardu (Albrychtowo alias Lepar), kuriam priklausė Andrešiūnų, Mažèlių, Andriejūnų kaimai ir karčema, ši kartą paveldètojas Kijevo vaivadystès sargybinis Rafaelis Landsbergis [Rafaelio Pranciškaus sūnėnas] ${ }^{46}$ Lieporų dvarą pardavė Malgūžès dvaro savininkui Ernestui Tyzenhauzui (Ernst von Tiesenhausen, * 1737$)^{47}$. Šis netrukus 1768 / 1771 m. Lieporų dvarą (Lepary) kartu su Gailiūnų kaimu ir karčema, Sodininkų, Mažèlių kaimais, buv. Karklynės palivarku (Karklinje alias Mało Lepary, kuriame kurị laiką buvo ịsikūręs girininkas) pardavè svainiui Karlui Frydrichui Frankui (Karl Friedrich von Pfeilitzer gen. Franck, 1735-1803, žmona Ieva Julijona iš Tyzenhauzų (Eva Juliana geb. von Tiesenhausen) $)^{48} .1771$ m. nurodoma, kad Starobudo stalininkas Jurgis

44 Akt inwentarza poddanych przy prawie wieczystym od ich mosci panow Sakinow małzonkow jego mosci panu Frankowi danego, 177909 09, in: LVIA, SA-68, 1. 1202-1203v.

45 [Sutartis dėl Lieporų (Anuševičių) dvaro pardavimo], 174104 04, in: LVIA, SA-15347, 1. $48-51$.

46 Apie Landsbergius (von Landsberg) žinoma tai, kad Lietuvos atšakos pradininku laikomas Eberhardas (Eberhard, †1652), kuris 1652 m. įsigijo Lašmenpamūšio (vok. Pomusz) ir Dylowkow dvarus. Jo anūkas - Rapolas Pranciškus (Rafael-Franz, †1754) buvo Albrechtavo (vok. Albrychtow) ir Juodeikių (vok. Judeiki) dvarų savininkas, 1741 m. vedè Mariją Elžbietą (Maria Elisabeth von Schroeders), vaikų neturèjo, linija išmirè. Jis $1754 \mathrm{~m}$. testamentu sūnènui Rapolui (Rafael) paliko Albrechtavo, o Juozapui - Juodeikių dvarus. Rapolas 1764 m. valdè Vengriškių (Woyryszek) ir Albrechtavo dvarus, buvo vedęs Konstanciją iš Kulešių (Konstanzia Kulesza) (Genealogisches Handbuch der baltischen Ritterschaften. (Herausgegeben von Verbänden des livländischen, estländischen und kurländischen Stammadels). O. Stavenhagen, heraus. Bd. 2: Kurland: 1930-1944, Görlitz: Verlag für Sippenforschung und Wappenkunde G. A. Strake (Inh. Hans Kretschmer), [1944], Lies. 9.-12, p. 660; Percy Schroeders, op. cit., p. 25, 43, 51), jo sesuo Eleonora ištekèjo už gretimo Medvilionių (Lieporų) dvaro savininko bajoro Pranciškaus Gosicko.

47 [Sutartis dèl Lieporų (Albrechtavo) dvaro pardavimo], 176304 03, in: LVIA, SA-15351, 1. $341-344$

48 Przyznanie wieczysto ugodliwego zapisu między jegomosci panami Tyzenhauzami y Frankami zaszłego, 176807 18/1773 07 16, in: LVIA, f. 351, ap. 1, b. 8 (SA-15269), l. 209-216; Przyznanie inwentarza majętnosci Lepar od jegomosci pana Tyzenhauza y Frankow jegomosci panu Tyzenhauzowi danego, 176806 23/1773 07 16, in: LVIA, f. 351, ap. 1, b. 8 (SA-15269), 1. 217-218; Przyznanie inwentarza majętnosci Lepar od jegomosci pana Tyzenhauza jegomosciom panom Frankom danego, 177105 05/1773 07 16, in: LVIA, f. 351, ap. 1, b. 8 (SA-15269), 1. 219-220. 
Grothusas (†1791, jo sesuo Ona Sibilè (Anna Sibylle von Grotthuss) ištekèjo už Goesų Lietuvos atšakos pradininko Oto Frydricho (Otto Friedrich von Goes)) dvarą, vadintą Albrychtowo alias Lepary, su karčema ir Mažèlių, Andrešiūnų, Andriejūnų (Indriliūnų) kaimais perleido tam pačiam Karlui Frydrichui Frankui ${ }^{49}$, o šis netrukus 1777 m. su Gailiūnų, Sodininkų, Mažèlių, Andrešiūnų kaimais ir buvusiu Karklynès palivarku - savo pusbroliui Ferdinandui (1723-1783) $)^{50}$. Surašytas apie 1780 m. baronų Frankų turtas (dvarai Lietuvoje bei Kurše ịkainoti: Sesavos (Sessau) - 75 000, Mėmelès (Memelhof) - 43 200, Lieporų - 71000 ir kt., namas Jelgavoje - 12 000, obligacijos - 23940 , iš viso - 225140 florinų), motinos dalis (52 000), skolos (76 650), likęs turtas (96 490 florinų) paskirstytas palikuonims: Luizai (13 784 2/7), Petrui (27 568 4/7), Frydrichui (27 568 4/7), Ernestui (27 568 4/7 florinų) ${ }^{51}$. 1775 m. Upytès dūmų tarifuose nurodyta, kad baronų Hanų (von Hahn) laikytą Lieporų dvarą (1 dūmas) sudarė Albertiškių palivarkas (Albertyszki, 1), Mažèlių (5), Andrešiūnų (Endruszuny, 2), Sodininkų (Saudyniki, 6), Gailiūnų (9), Karklynès (1), Andriejūnų (Andrehuny, 1) kaimai (iš viso 26 dūmai) ${ }^{52}$. 1790 m. padūmès tarifuose Petro Franko (Peter Georg von Pfeilitzer gen. Franck, 1752-1825, Ferdinando sūnus) Lieporų dvare (1 dūmas) nurodyta esant Albertiškių palivarką (Olbrychtow, 1 ir karčema), Mažèlių (5), Sodininkų (Sodyniki, 6), Gailiūnų (9, kurių 1 karčema), Andrešiūnų (Andreszuny, 2), Andriejūnų (Andreiuny, 1), Karklynès (1) kaimai (iš viso 26 dūmai) ${ }^{53}$. Vèliau, 1816 m., Petro viduriniojo brolio Jurgio Franko (Georg Friedrich Ernst von Pfeilitzer gen. Franck, 1760-1830) valdytame Lieporų (kartu su Albrechtavu) dvare surašyti 22 dūmai (ūkiai su 104 ,vyriškom“ sielom) ${ }^{54}$. Tuo tarpu jauniausiasis brolis Ernestas (Ernst Johann von Pfeilitzer gen. Franck, 1762-1847) 1797 m. ịsigijo Daunoravos dvarą.

49 Przyznanie wieczysto przodaznego prawa na dobra Albrychtow alias Lepary od jegomosciow panow Grotuzow jegomosci panom Frankom danego, 177110 14/1773 07 16, in: LVIA, f. 351, ap. 1, b. 8 (SA-15269), 1. 221-223.

50 Przyznanie inwentarza majętnosci Lepar, Albrychtowa seu Lepar od wielmoznych Frankow wielmożnemu Frankowi danego, 177703 15, in: LVIA, f. 351, ap. 1, b. 12 (SA-15273), 1. 141-147.

51 Dokumentas be datos, tikètina, sudarytas prieš tẻvo Ferdinando mirti $1783 \mathrm{~m}$. Archyvo byloje ant lapo pieštuku užrašyta 1826 m. data, matyt, reiškianti perrašymo datą; Op. cit., in: LVVA, f. 1100, ap. 13, b. $1085,1.33$.

52 Naugarduko, Minsko ir Trakų vaivadijų bei Lydos, Upytės, Oršos ir Rečicos pavietų dūmų ir padūmės mokesčio tarifai (Nowogrodzkie, Minskie, Trockie województwa, Lidzki, Upitski, Orzszanski i Rzeczycki powiaty), 1775, in: LVIA, f. 11, ap. 1, b. 1588 (SA-18167), 1. 45v.

53 Upytès pavieto dūmų tarifas (Taryfa dymów), 1790, in: LVIA, f. 11, ap. 1, b. 707 (SA-3370), l. 8v.

54 Дело об исчислении расходов на составление ревизских сказок и о злоупотреблениях казенной палаты. Сведения о количестве дымов и душ по имениям, 1816-1826, in: LVIA, f. 391, ap. 6, b. 123, l. 191. 
Kaip matyti, 1763-1773 m. minimas Lieporų-Albrechtavo pavadinimas byloja, kad tuomet tai buvo atskira valda (be didelių Gailiūnų, Sodininkų kaimų ir Karklynès palivarko) ir jos sodyba buvo ịsikūrusi vèliau žinomo Albertiškių palivarko vietoje. Labai tikètina, kad tarp 1768-1775 m. ši valda baronų Frankų jau buvo sujungta su jų valdoma Lieporų-Karklyne, nes jau 1775 m., 1790 m. padūmès tarifuose, 1777 m. inventoriuje kartu minimi abu Lieporų ir Albertiškių dvarai (Lepar y Albrychtow alias Lepar). Lieporų-Karklynės dvaro sodyba egzistavo jau XVI a. - tai liudija minėti šaltiniai bei LVVA (Pfeilitcerių-Frankų (von Pfeilitzer gen. Franck) bylose) saugomas Lieporų (Karklynės) dvaro archyvo 1589-1773 m. aprašas ${ }^{55}$, kurio dalies dokumentai (1662-1690) saugomi bütent Frankų fonde ${ }^{56}$, o likusios dalies likimas kol kas nėra žinomas. Šios Lieporų dvaro valdos abiejų Albertiškių ir Karklynės sodybų lokalizavimui, chronologijai bei jos struktūrai nustatyti reikalingi papildomi rašytinių šaltinių ir archeologiniai tyrimai.

\section{1 lentelè. Lieporų (Grothusų) dvaro dūmų suvestine் $\dot{e}^{57}$}

\begin{tabular}{|c|c|c|c|c|c|c|c|c|c|}
\hline $\begin{array}{l}\text { Metai / dvaras, } \\
\text { palivarkas, kaimas, } \\
\text { girininkija }\end{array}$ & 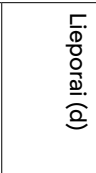 & 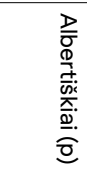 & 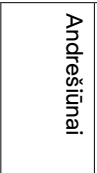 & 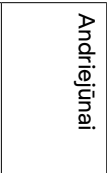 & 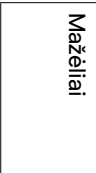 & 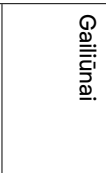 & 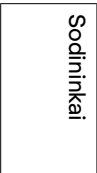 & 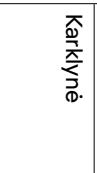 & $\begin{array}{l}\overline{\text { कx }} \\
\stackrel{x}{\infty} .\end{array}$ \\
\hline $1717 \mathrm{~m}$. & + & & & & $3+1 \mathrm{t}$ & & & $+p$ & 14 \\
\hline $1741 \mathrm{~m}$. & + & & $1+1 \mathrm{t}$ & 1 & 2 & & & & 5 \\
\hline $1763 \mathrm{~m}$. & + & $1 \mathrm{k}$ & 3 & 1 & 2 & & & & 6 \\
\hline $1764 \mathrm{~m}$. & + & & & & & & & & 24 \\
\hline $1771 / 1773$ m. & + & $1 \mathrm{k}$ & 3 & 3 & 3 & & & & 9 \\
\hline 1768/1773 m. & + & & & & 3 & $9+1 \mathrm{k}$ & 5 & $1 \mathrm{~g}$ & 17 \\
\hline 1771/1773 m. & + & & & & 3 & $10+1 \mathrm{k}$ & 5 & $1 p$ & 20 \\
\hline $1777 \mathrm{~m}$. & 1 & 1 & 2 & 1 & 2 & $8+1 k+3 t$ & $6+3 t$ & $1 p$ & 26 \\
\hline $1775 \mathrm{~m}$. & 1 & 1 & 2 & 1 & 5 & 9 & 6 & 1 & 26 \\
\hline $1783 \mathrm{~m}$. & + & & & & & & & & 26 \\
\hline $1790 \mathrm{~m}$. & 1 & $1+1 \mathrm{k}$ & 2 & 1 & 5 & $9+1 \mathrm{k}$ & 6 & 1 & 26 \\
\hline $1816 \mathrm{~m}$. & 1 & 1 & & & & & & & 22 \\
\hline 1848/1854 m. & + & & + & + & + & + & + & & 18 \\
\hline $\begin{array}{l}1894 \text { m. priklausę buv. } \\
\text { baudžiauninkams }\end{array}$ & & & & $\begin{array}{l}22 \mathrm{~d} . \\
2300 \mathrm{~s} .\end{array}$ & $\begin{array}{l}116 \mathrm{~d} . \\
312 \mathrm{~s} .\end{array}$ & $\begin{array}{l}130 \mathrm{~d} . \\
1842 \mathrm{~s} .\end{array}$ & $91 \mathrm{~d}$. & $\begin{array}{l}6 \mathrm{~d} . \\
58 \mathrm{~s} .\end{array}$ & $\begin{array}{l}366 \mathrm{~d} . \\
2112 \mathrm{~s} .\end{array}$ \\
\hline
\end{tabular}


1854 m. Grothusų Lieporų dvaro valda apėmè 1037 dešimtines žemės, kurios 18 dešimtinių sudarė sodybos su daržais, sodais, 270 - ariamos, 108 - pievų, jai priklausė Andrešiūnų, Andriejūnų (Indriliūnų), Mažèlių, Sodininkų ir Gailiūnų kaimai (iš viso 18 dūmų) su 108 vyrų ir 112 moterų „sielomis“, iš ju darbingu - 67 vyru ir 70 moterų $^{58}$. 1878 m. valda apèmė 400 dešimtinių 1208 kv. sieksnius ${ }^{59}$. $1881 \mathrm{~m}$. Kauno gubernijos žemvaldžių sąrašuose nurodoma, kad valdą sudarè 315 dešimtinių dirbamos žemès, 25 blogos ir 140 miško (iš viso 480 dešimtinių, karčemų, malūnų nėra ${ }^{60}$.

1812 m. sudarytame Pašvitinio parapijos ${ }^{61}$ ir 1843 m. Šiaulių apskr. žemėlapiuose ${ }^{62}$ apytikriai pažymėtos Lieporų (д. Лепары) su netiksliomis Gailiūnų (Гаупуны), Sodininkų (Соденики) ir Mažèlių (Мажеле) kaimų vietomis ir gretimų dvarų valdos [žr. 2 il.]. Šią informaciją (ribas su gretimais dvarais) gerokai patikslina $1885 \mathrm{~m}$. sudarytas valdos planas (situacija po 1861 m. valstiečių reformos). Valda plytėjo ì rytus nuo Lieporo upelio, kompaktiškai nutịsusi šiaurės-pietų kryptimi, o kairiajame upelio krante, tarsi apendiksu i Vigantų-Brašo Lieporų dvaro valdą, buvo ịsiterpusi jos tąsa (87 d. 804 kv. sieks. / 95 ha, vėliau žinoma kaip Valdhofo palivarkas). Sunku pasakyti, ar ši teritorija nuo seno priklausè, ar buvo igyta vėliau iš gretimo Lieporų dvaro. 2020 m. girininkas Gediminas Vitkauskas Ažzolynès miške (pavadinimas nuo kadaise greta buvusio Ažžolynės palivarko) rado Lieporu dvaro valdos šiaurinès ribos kampinị riboženkli (X: 6243799, Y: 491828). Jis žymėjo ribą su gretimu Bergo valdytu Juodeikių dvaru (1885 m. planas).

Išliko $1885 \mathrm{~m}$. sudarytas Lieporų dvaro valdos planas [4 il. $]^{63}$. 1894 m. dvaro ịkeitimo Vilniaus valstybės dvarininkų žemės bankui byloje patikslintos naudmenos - išskirti 5 sklypai, o plane pažymėtos Lieporų dvaro, Albertiškių-Albertshofo (Албертсгофъ), Miežinių-Valdhofo (Валдгофъ), Karklynės-Ozolų (rus. Озоль, liet. Ažzuolų, Ažzuolynės) palivarkų sodybos, Frankynès karčema (Карчма Франкенъ), nurodytas arimų, pievų, miško, upių, kapinių (su žvyrduobe, kurios vietoje buvo V-XIII a. žiemgalių

58 Выписки из инвентарей помещичьих имений и расписки владельцев о принятии инвентарных правил по Шавельскому уезду, 1848/1854, in: LVIA, f. 378, BS-1848, b. 2118, l. 302-303. 59 Viliaus Grotuso ịpèd., in: Lietuvos centrinis valstybės archyvas (toliau - LCVA), f. 1248, ap. 2, b. 1844, 1.9 .

60 Алфавитный список землевладельцев Ковенской губернии (по 1-е сентября 1881 года), Ковно: Типография губернского правления, 1882, 1. 97.

61 Pašvitinio ir Linkuvos parapijų žemèlapis, 1812, in: LVIA, f. 525, ap. 8, b. 1582, 1. 13.

62 Карта Шавельского у. Ковенской губернии, 1843, in: LVIA, f. 526, ap. 7, b. 5444.

63 Op. cit., in: LVIA, f. 542, ap. 1, b. 262, l. 1. 


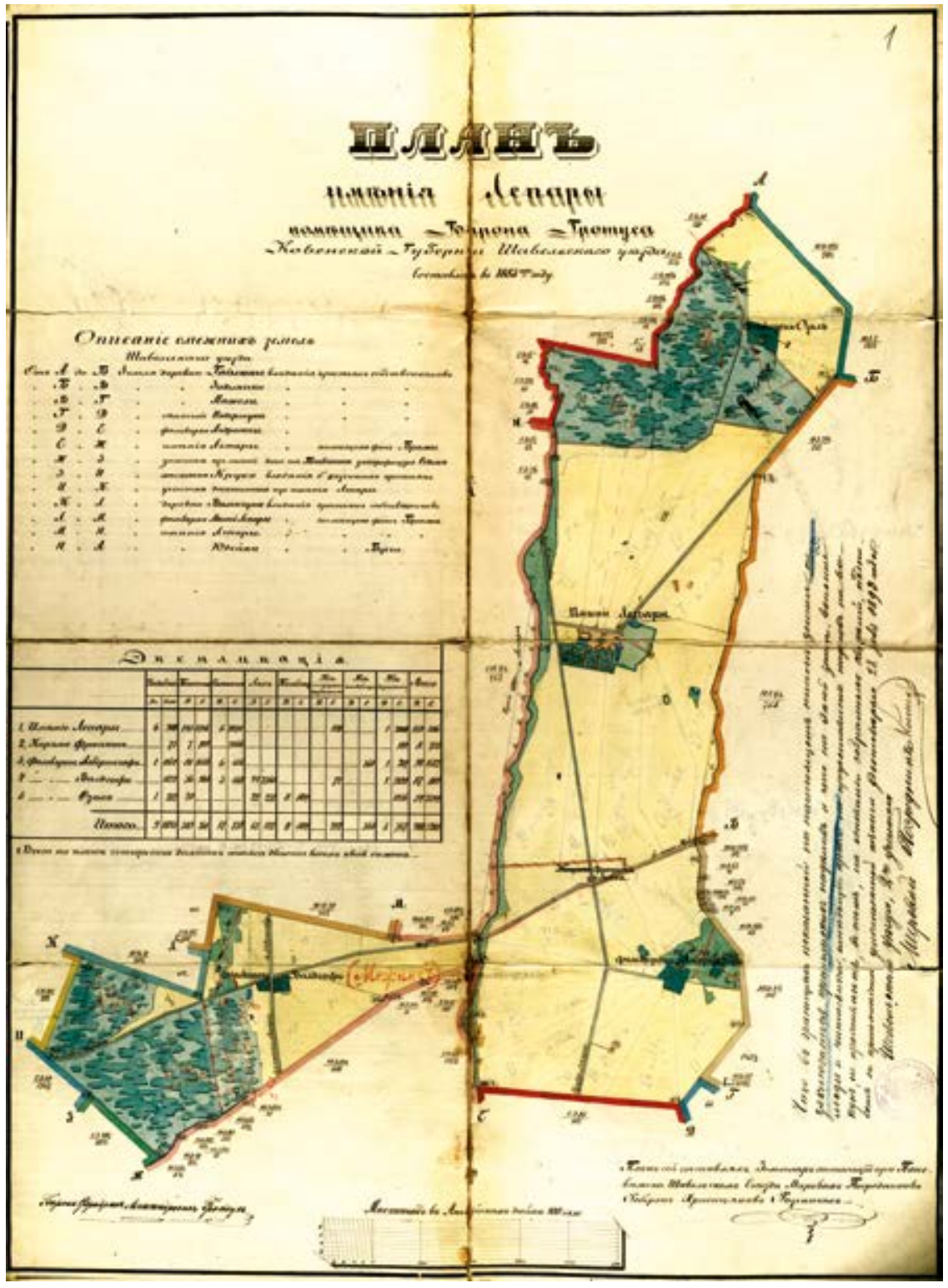

4.

Lieporų dvaro valdos planas, 1885, braižè Robertas Plan of the Lieporai manor property. 1885 Rozentalis, LVIA, f. 542, ap. 1, b. 262, l. 1 
kapinynas ir iš čia ị Kuršo provincijos muziejų 1912-1913 m. pateko keliasdešimt radinių), kelių, iš viso - 400 dešimtinių 1208 kv. sieksnių plotas. Byloje minima 10 naudmenų laukų po 14 dešimtinių (1, 7 - pūdymas, 2 - rugiai, 3, 4 - dobilai, 5 - vasarojus su miežiais, linais, bulvèmis, 6 , 10 - avižos, 8 - kviečiai, 9 - miežiai), o plane pieštuku jie buvę pažymėti ${ }^{64}$. Kaip matyti, pavadinimai ilgainiui kito - buvo duotos latviškos (Karklynės $>$ Ozol (lat. ozolu = ąžuolų), Mežin (lat. meža = miško)) arba vokiškos formos (Albertiškių-Albertshofo, Miežinių-Valdhofo). Tuomet valda ribojosi su gretimų kaimų Gailiūnų (A-B), Sodininkų (B-V), Mažèlių (V-G), Andrešiūnų (G-D), Andriejūnų (D-E) (visi iki 1861 m. priklausė Grothusų Lieporų dvarui), Bergo Juodeikių (N-L), Brašo Lieporų dvaro (E-Ž, L-M, M-N) ir Valančiūnų (K-L, iki 1861 m. priklausè Brašo Lieporų dvarui), Kriukų mst. valstybinių valstiečių (Z-I) sklypais.

2 lentelè. Lieporų (Grothusų) dvaro, palivarkų naudmenų suvestinè $1894 \mathrm{~m}^{65}$

\begin{tabular}{|c|c|c|c|c|c|c|c|c|c|}
\hline Sklypas & Sodybų & Arimų & Pievų & Miško & $\begin{array}{l}\text { Iš viso } \\
\text { geros }\end{array}$ & Upių & Kapinių & Kelių & Iš viso \\
\hline Lieporų dv. & $6 \mathrm{~d} .980 \mathrm{~s}$. & $\begin{array}{l}143 \mathrm{~d} . \\
1736 \mathrm{~s} .\end{array}$ & $\begin{array}{l}6 \mathrm{~d} . \\
2070 \mathrm{~s} .\end{array}$ & - & & $920 \mathrm{~s}$. & - & 1d. $2000 \mathrm{~s}$. & 159 d. 506 s. \\
\hline Frankynès k. & $73 \mathrm{~s}$. & 7 d. $709 \mathrm{~s}$. & $2166 \mathrm{~s}$. & - & & - & - & $184 \mathrm{~s}$. & $8 \mathrm{~d} .732 \mathrm{~s}$. \\
\hline Albertshofo $p$. & 1s. $1164 \mathrm{~s}$. & $\begin{array}{l}87 \mathrm{~d} . \\
1656 \mathrm{~s} .\end{array}$ & $635 \mathrm{~s}$. & - & & - & $360 \mathrm{~s}$. & 1d. $207 \mathrm{~s}$. & 90 d. 1622 s. \\
\hline Valdhofo $p$. & $1824 \mathrm{~s}$. & $\begin{array}{l}39 \mathrm{~d} . \\
1628 \mathrm{~s} .\end{array}$ & $9 \mathrm{~d}$. & $\begin{array}{l}35 \mathrm{~d} . \\
2360 \mathrm{~s} .\end{array}$ & & $72 \mathrm{~s}$. & - & 1d. $2120 \mathrm{~s}$. & 87 d. 804 s. \\
\hline Ozolų p. & 1d. $252 \mathrm{~s}$. & $\begin{array}{l}31 \mathrm{~d} . \\
804 \mathrm{~s} .\end{array}$ & - & $\begin{array}{l}22 \mathrm{~d} . \\
232 \mathrm{~s} .\end{array}$ & & - & - & $1056 \mathrm{~s}$. & 54 d. 2344 s. \\
\hline Iš viso: & 9 d. 1893 s. & $\begin{array}{l}289 \mathrm{~d} . \\
261 \mathrm{~s} .\end{array}$ & $\begin{array}{l}17 \mathrm{~d} . \\
739 \mathrm{~s} .\end{array}$ & $\begin{array}{l}57 \mathrm{~d} . \\
192 \mathrm{~s} .\end{array}$ & $\begin{array}{l}394 \mathrm{~d} . \\
1489 \mathrm{~s} .\end{array}$ & $992 \mathrm{~s}$. & $360 \mathrm{~s}$. & 5 d. $767 \mathrm{~s}$. & 400 d. 1208 s. \\
\hline
\end{tabular}

1903 m. Kauno gubernijos gyvenviečių sąraše nurodyta, kad Lieporų dvare gyveno 52 gyventojai, Albertiškių pal. - 12, Karklynės vnk. 23, Miežiniuose - 15, Franko karčemoje - $14^{66}$, o 1923 m. visuotinio surašymo

64 Op. cit., in: LVIA, f. 542, ap. 1, b. 262, 1. 2-8.

65 Sudaryta pagal: op. cit., in: LVIA, f. 542, ap. 1, b. 262, l. 4v, 32.

66 Алфавитный список населенных месть Ковенской губернии, Ковно: Типография губернского правления, 1903, р. 362, 395, 403, 408, 448. 
metu Lieporų dvare registruoti 47 gyventojai, Albertiškių pal. - 22, Karklynès pal. -23 , Miežinių pal. - 10, Frankienès vns. $-8^{67}$.

Iki žemės reformos $1922 \mathrm{~m}$. dvaras valdė 429,51 ha žemès, nenusavinta palikta 151 ha $5500 \mathrm{~m}^{2} .^{68}$ Vykdant žemès reformą buvo surašytas Danieliaus Grothuso ịpėdinių Lieporu dvaras (203,72 ha), Albertiškių (99,06 ha) ir Miežinių (48,06 ha), Karklynès (78,66 ha) palivarkai, iš jų miško (78 ha), dvaro sodybos trobesiai.

Be to, Lieporų Grothusai turejjo ir namą Mintaujoje, Aleksandro pr. $4^{69}$ (sudegė 1944 m., dab. Zemgales pr. 10). Kiti Grothusai (sav. Vilhelmas (Wilhelm Anton, 1878-1963) $1901 \mathrm{~m}$. paveldejjo pagal tèvo Aleksandro Juozapo (1820-1906) testamentą) valdè ir netoliese esantị Vengriškių dvarą (290 ha, iš jų 123,4 ha miško) $)^{70} .1940$ m. rugpjūčio 18 d., vykdant vokiečiu dvarų ir nuosavybės apskaitą, nurodyta, kad Lietuvos piliečio Jono Grothuso Lieporų dvaras valdè 101,16 ha žemès, kuri i žemès fondą dar neperimta, turtas nenusavintas, komisaras nepaskirtas ${ }^{71}$.

\section{Sodyba XVIII-XIX a.}

Minètuose XVIII a. pirkimo-pardavimo aktų nuorašuose, lyginant su tyrinėtais Daunoravos ar Malgūžių (1763), Viganto Lieporų (1759) dvarais, nėra surašytų išsamių Lieporų (Grothusų) dvaro sodybos inventorių, nedetalizuoti pasėliai. Tarkim, lakoniškai apibūdinta dvaro valda ir sodyba:

pats [Anusevičių] dvaras su pastatais ir klojimu, be tvorų (?), remontas nuo pamatų reikalingas, su javais (pasèliais) laukuose pasètais, su ariama ir neariama žeme, su vaisių sodais ir apynynais; $(1741)^{72}$

viso dvaro Albrechtavo arba Lieporu (Albrychtowo alias Lepar) dvaro trobesiai: gyvenamas namas (rum mieszkalny) <..> su kambariais, durimis, langais, stalais ir grindimis (posadzkami) ir stogu, remontas nereikalingas, durys geležiu kaustytos, grindys < ...>; su klojimu gerai laikomu ir prie jo esančiomis daržinėmis < ...>

67 Lietuvos apgyventos vietos: pirmojo visuotinojo Lietuvos gyventoju $1923 \mathrm{~m}$. surašymo duomenys, sud. Biržiška V., Kaunas: Centralinis statistikos biuras, 1925, t. VIII, p. 295-296.

68 Op. cit., in: LCVA, f. 1248, ap. 2, b. 1844, 1. 5-10, 32.

69 Adolf Richter, Adolf Richters Baltische Verkehrs- und Adressbücher, Bd. 2: Kurland, Riga: Selbstverlag des Herausgebers, 1912, p. 17.

70 Grotuzas Vilhelmas, in: LCVA, f. 1248, ap. 2, b. 1845, 1. 9, 12.

71 Vokiečiu tautybès savininkų ūkių atskirose apskrityse sąrašai, 1940-1941, in: LCVA, f. R-764, ap. 1a, b. 153, 1. 29, 95 .

72 Op. cit., in: LVIA, SA-15347, 1. 48v, 50v. 
su svirnais pastatytais, remontas nereikalingas, ir spynomis duryse; su abare ir tvartais, <...> remontas nereikalingas; su varykla (bravoru) ir gera pirtimi, ir palivarku (šeimynine) su piekarnia [patalpa su duonkepe krosnimi]; (1763) ${ }^{73}$ paminėtą Albrechtavo, arba vadinamą Lieporų, dvarą su dvaro pastatais ir kluoniena, karčema tam dvarui priklausančiais, su kaimais ir pavaldiniais kaimuose gyvenančiais, su jų žmonomis, vaikais <...>, su arkliais, gyvuliais raguotais ir neraguotais; <...> su visomis pajamomis, išskyrus vieną valstiečio - vardu Karolio sūnaus ir audejjo Jono; su tvenkiniais ir kūdromis (stawami sadzowkami, stawiszczami), upėmis, upeliais, užutėkiais, žeme ariama ir neariama, gojais, miškais, krūmynais, šienaujamomis pievomis, (moroznemi), ir balomis, nuo seno valda riboženkliais pažymèta, su nupirktomis [papildomai], apkeistomis žemėmis (ograniczeniach dawnych specificie wyrazonemi, z przykupkami, zamianomi) su sodais vaisių ir apynynais, $<\ldots>$ prie to su visais dvaro gyvuliais, su katilais [graznymi...], varykla (bravoru) iki šiol Albrechtave esančiais. (1773) ${ }^{74}$

Išsamiai XVIII a. apibūdinti tik kaimų ūkiai (nuo 5 iki 20) su šeimos sudėtimi (vertingas genealoginis šaltinis), valstiečių prievolės (tarp jų ir pastotès ị Rygą 1741 m., 1763 m.). Lyginant su kitu vokišku Daunoravos dvaru, matyti skirtumai - Lieporuose vien lietuvių pavardès, o ūkiuose mažiau žmonių, o Daunoravoje dominavo latviškos ūkininkų šeimininkų pavardès, ūkiuose gyveno vidutiniškai 15-16 žmonių.

1885 m. plane Lieporų dvaro sodyboje (6 deš. 980 kv. sieks.) pažymėtas netaisyklingos trapecijos formos kiemas su ponų namu šiaurinėje dalyje (A-1, su 1 prieangiu, 2 nedidelèmis verandomis galuose), priešais juos apskrita klomba ir svirnas daiktams (lobynas (?) (A-6)), užpakalinėje pusėje i pietus stačiakampiais $(3 \times 4)$ suformuotas parkas su sodu. Vakarinėje pusėje glaudèsi ūkinè dalis su diendaržiu galvijams (A-4), arklide-vežimine (A-3), daržine (A-5), svirnu (A-2), ị rytus prie kūdros išdèstyti oficina (A-7) su paukštide (A-8), tvartu darbininku gyvuliams (A-9). Atokiau dèl priešgaisrinių sumetimų buvo pastatyta kalvè (A-10, turi būti A-11) su kumetynu (A-11, turi būti A-10) (irgi prie kūdros, šiaurès rytuose) ir klojimas (A-12) rytuose. Nuo dvaro sodybos ị pietus ir šiaure pieštuku pažymėtos 2 daržinès javams laikyti (A-14, 15, хлебнь сарай). Dvaro sodyboje būta 2 kūdrų, 


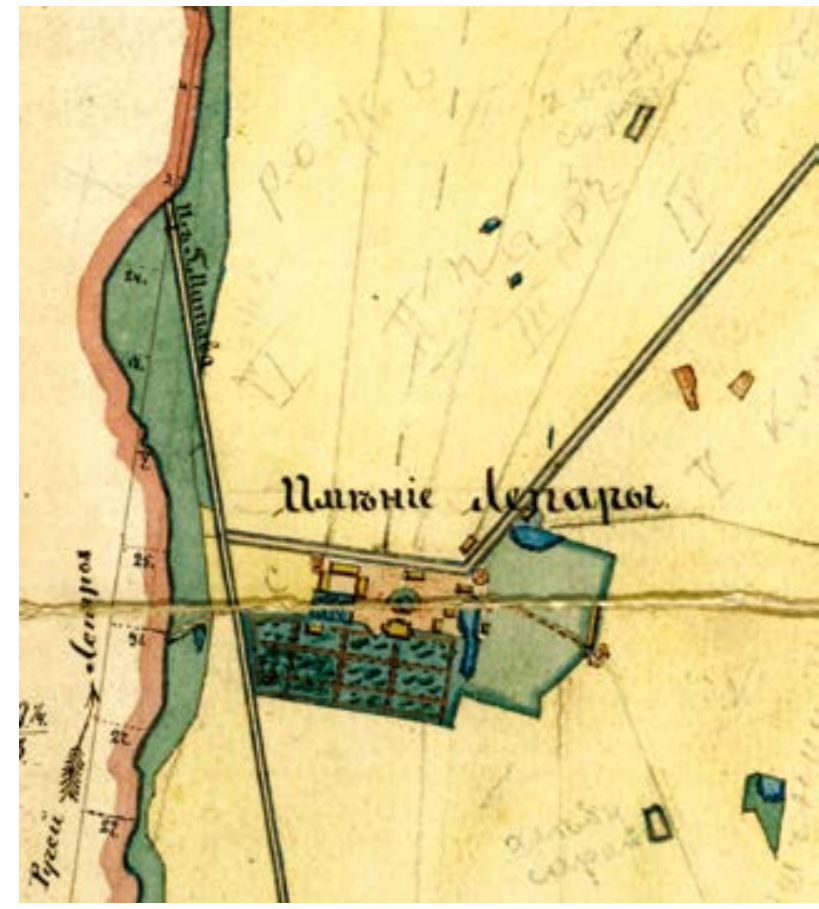

5.

Lieporų dvaro sodyba, plano fragmentas, 1885, LVIA, f. 542 , ap. 1 , b. $262,1.1$

Plan of the Lieporai Manor (detail), 1885

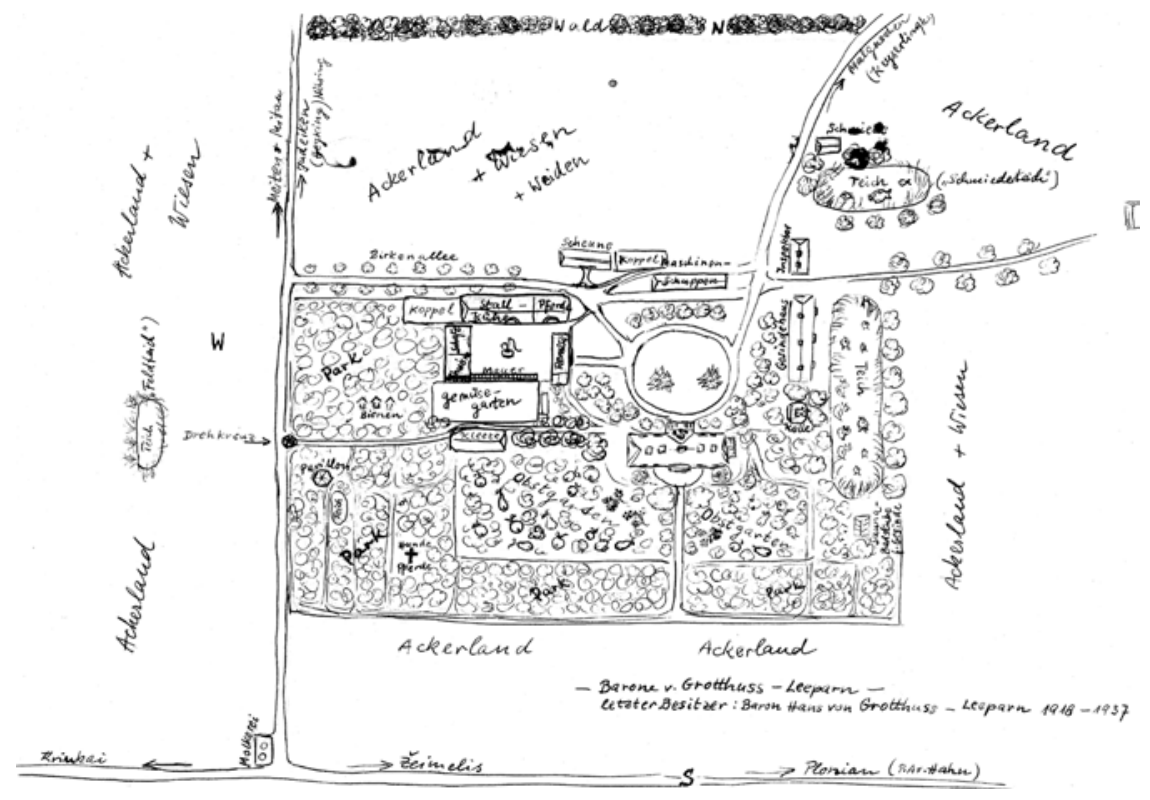

6.

Lieporų dvaro sodybos planas, sudare Sibilė Grothus (Sybille Dagny Benigna Nadine von Grotthuss)

Plan of the Lieporai Manor 


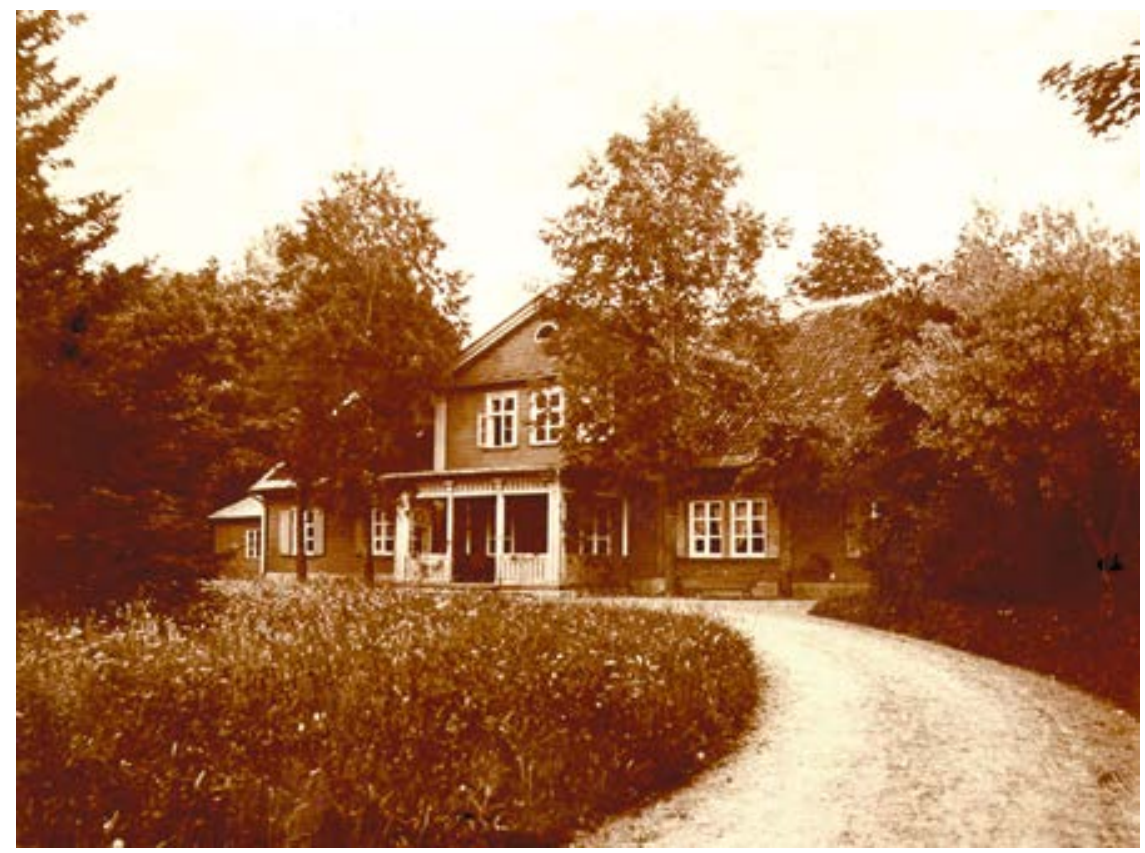

$$
7 .
$$

Ponų namas (A-1) su priestatu, klomba iš šiaurès, apie 1910, Johano Grothuso nuotrauka

Master's house (A-1) with an annex and a flowerbed in the north ca. 1910

tikriausiai suformuotos kasant molį trobesių statybai, kurių 1 glaudèsi prie dvaro sodybos kumetyno, ūkinių pastatų ir parko rytuose - taip pagyvino sodybos kraštovaizdį, kita buvo iškasta atokiau prie kalvès. Šakniavaisiu daržas buvo įrengtas tarp svirno ir ūkinio kiemo. Sodas apėmė 2 dešimtines, kuriame augo 300 obelų, kriaušiu [5-13 il.]. Taigi dvaro sodybą, kaip ir kitas to laikmečio vidutinių dvarų sodybas, sudarè 4 dalys - reprezentacinė, ūkinè, atokiau buvo kluoniena ir gamybinè su kalve, o laukuose dar 2 daržinės javams laikyti. Dvaro ịkeitimo bankui byloje $1894 \mathrm{~m}$. surašyti dvaro sodybos trobesiai, kur, be gyvenamojo ponų namo, nurodyti dar 14 pastatu, 6 šuliniai ${ }^{75}$, tačiau nėra minima pirtis ir varykla. $1908 \mathrm{~m}$. ìvardyta jau 17 pastatu (papildomai - molinis kumetynas ir medinè daržinè), o visas dvaras ¡̨kainotas 57300 rub., nuspręsta suteikti 34300 rub. paskolą ${ }^{76}$.

75 Op. cit., in: LVIA, f. 542, ap. 1, b. 262, 1. 4v.

76 Дело о перезалоге им. Лепары Шавельского у. Ковенской губ. барона Гротуса Ф. А., 1907-1916, in: LVIA, f. 542, ap. 1, b. 943, 1. 25-26, 29. 


\section{3 lentelè. Lieporų (Grothusų) dvaro, palivarkų pastatų suvestinè 1894 m.77}

\begin{tabular}{|c|c|c|c|c|c|c|c|c|c|c|}
\hline \multirow{3}{*}{ 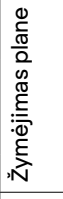 } & \multirow{3}{*}{$\begin{array}{l}\text { Pastato pavadinimas ir } \\
\text { paskirtis } \\
\text { Lieporų dvaras }\end{array}$} & \multicolumn{3}{|c|}{ Medžiaga } & \multicolumn{5}{|c|}{ Pastatų aprašymas } & \multirow{4}{*}{\begin{tabular}{|l} 
Vertè \\
2500 \\
\end{tabular}} \\
\hline & & \multirow{2}{*}{ 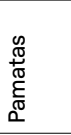 } & \multirow{2}{*}{$\begin{array}{l}0 \\
0 \\
\frac{0}{0} \\
\dot{0} \\
\end{array}$} & \multirow{2}{*}{$\begin{array}{l}n \\
0 \\
0 \\
0 \\
0 \\
\text { c } \\
\end{array}$} & $\stackrel{\frac{\infty}{6}}{=}$ & $\begin{array}{l}\frac{\infty}{0} \\
\frac{0}{2}\end{array}$ & 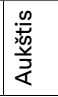 & \multirow{2}{*}{ 竞 } & \multirow[t]{2}{*}{$\begin{array}{l}\text { Šildymas } \\
\text { krosnimis }\end{array}$} & \\
\hline & & & & & \multicolumn{3}{|c|}{ sieksniais } & & & \\
\hline$A-1$ & 1. Ponų namas & akm. & med. & čerp. & $15+2$ & 5 & $1 \frac{1}{2}$ & tvirtas & $\begin{array}{l}12 \text { olandiškụ } \\
\text { koklių, } 1 \\
\text { akmeninis }^{78}\end{array}$ & \\
\hline$A-2$ & 2. Svirnas & akm. & med. & čerp. & 9 & 5 & $11 / 2$ & tvirtas & & 800 \\
\hline$A-3$ & 3. Arklidè-karietinè & akm. & med. & gont. & 10 & 4 & $1 \frac{1}{2}$ & tvirtas & & 800 \\
\hline$A-4$ & 4. Diendaržis-arklidè & akm. & med. & gont. & 21 & 6 & $1 \frac{1}{2}$ & tvirtas & & 2000 \\
\hline$A-5$ & 5. Daržinè & akm. & med. & gont. & 10 & 4 & $1 \frac{1}{2}$ & tvirtas & & 1000 \\
\hline$A-6$ & 6. Daržinè rakandams & akm. & med. & gont. & 12 & 3 & $11 / 2$ & tvirtas & & 300 \\
\hline$A-7$ & 7. Oficina & akm. & molio & čerp. & 15 & 4 & $11 / 2$ & tvirtas & $\begin{array}{l}4 \text { rusiškos } \\
\text { krosnys }^{79}\end{array}$ & 1300 \\
\hline$A-8$ & 8. Paukštidè & akm. & med. & gont. & 3 & 3 & 1 & tvirtas & & 50 \\
\hline$A-9$ & $\begin{array}{l}\text { 9. Tvartas darbininku } \\
\text { galvijams }\end{array}$ & akm. & molio & gont. & 4 & 3 & 1 & tvirtas & & 50 \\
\hline A-10 & 10. Kalvè & akm. & molio & čerp. & 6 & 3 & $1 \frac{1}{2}$ & tvirtas & & 200 \\
\hline A-11 & 11. Kumetynas & akm. & \begin{tabular}{|l} 
akm.- \\
med.
\end{tabular} & čerp. & 5 & 5 & $1 \frac{1}{2}$ & tvirtas & $\begin{array}{l}2 \text { rusiškos } \\
\text { krosnys } \\
\end{array}$ & 200 \\
\hline A-12 & 12. Klojimas & akm. & med. & gont. & 10 & 4 & $1 \frac{1}{2}$ & senas & & 300 \\
\hline A-13 & 13. Kiaulidè & akm. & med. & gont. & 8 & 4 & $1 \frac{1}{2}$ & tvirtas & & 100 \\
\hline A-14 & 14. Daržinè [javams] & med. & stulpų & gont. & 12 & 5 & $1 \frac{1}{2}$ & nauja & & 200 \\
\hline A-15 & 15. Daržinè [javams] & med. & stulpų & šiaud. & 12 & 5 & $1 \frac{1}{2}$ & nauja & & 200 \\
\hline \multicolumn{9}{|c|}{ Alberthofo palivarkas } & Iš viso & 10000 \\
\hline B-1 & 16. Klojimas & akm. & molio & gont. & 14 & 4 & $11 / 2$ & tvirtas & & 1000 \\
\hline B-2 & 17. Diendaržis & akm. & molio & gont. & 10 & 4 & $1 \frac{1}{2}$ & tvirtas & & 800 \\
\hline B-3 & 18. Arklidè & akm. & molio & gont. & 6 & 3 & $11 / 2$ & tvirtas & & 200 \\
\hline B-4 & 19. Kiaulidè & akm. & molio & gont. & 6 & 3 & $11 / 2$ & tvirtas & & 200 \\
\hline B-5 & 20. Namas & akm. & molio & čerp. & 6 & 3 & $1 \frac{1}{2}$ & tvirtas & 2 krosnys & 300 \\
\hline B-6 & 21. Svirnas & akm. & molio & gont. & 8 & 4 & $1 \frac{1}{2}$ & tvirtas & & 350 \\
\hline $\mathrm{B}-7$ & 22. Pirtis & akm. & molio & čerp. & 6 & 3 & $1 \frac{1}{2}$ & tvirtas & 2 krosnys & 300 \\
\hline$B-8$ & 23. Darbininkų diendaržis & akm. & molio & šiaud. & 10 & 3 & $1 \frac{1}{2}$ & tvirtas & & 500 \\
\hline B-9 & 24. Daržinè javams & med. & stulpų & šiaud. & 12 & 5 & $1 \frac{1}{2}$ & tvirtas & & 350 \\
\hline \multicolumn{9}{|c|}{ Mežinhofo palivarkas } & Iš viso & 4000 \\
\hline C-1 & 25. Namas & akm. & med. & gont. & 7 & 3 & $1 \frac{1}{2}$ & tvirtas & & 350 \\
\hline $\mathrm{C}-2$ & 26. Svirnas & akm. & molio & šiaud. & 5 & 3 & $1 \frac{1}{2}$ & tvirtas & & 250 \\
\hline $\mathrm{C}-3$ & 27. Klojimas & akm. & med. & šiaud. & 11 & 4 & 1 & tvirtas & & 300 \\
\hline C-4 & 28. Diendaržis & akm. & molio & šiaud. & 13 & 4 & $1 \frac{1}{2}$ & tvirtas & & 300 \\
\hline$C-5$ & 29. Daržinè rakandams & akm. & med. & šiaud. & 11 & 2 & 1 & tvirtas & & 200 \\
\hline \multicolumn{9}{|c|}{ Frankynès karčema } & Iš viso & 1400 \\
\hline D-1 & 30. Namas-karčema & akm. & molio & gont. & 9 & 4 & $11 / 2$ & sena & 3 krosnys & 350 \\
\hline $\mathrm{D}-2$ & 31. Daržinè & akm. & med. & gont. & 5 & 4 & $11 / 2$ & tvirtas & & 250 \\
\hline \multicolumn{10}{|c|}{ 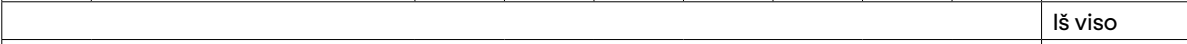 } & 600 \\
\hline & & & & & & & & & Iš viso & 16000 \\
\hline
\end{tabular}

77 Sudaryta pagal: op. cit., in: LVIA, f. 542, ap. 1, b. 262, l. 10-11.

78 Turimas omeny židinys.

79 Turima omeny duonkepès krosnys. 


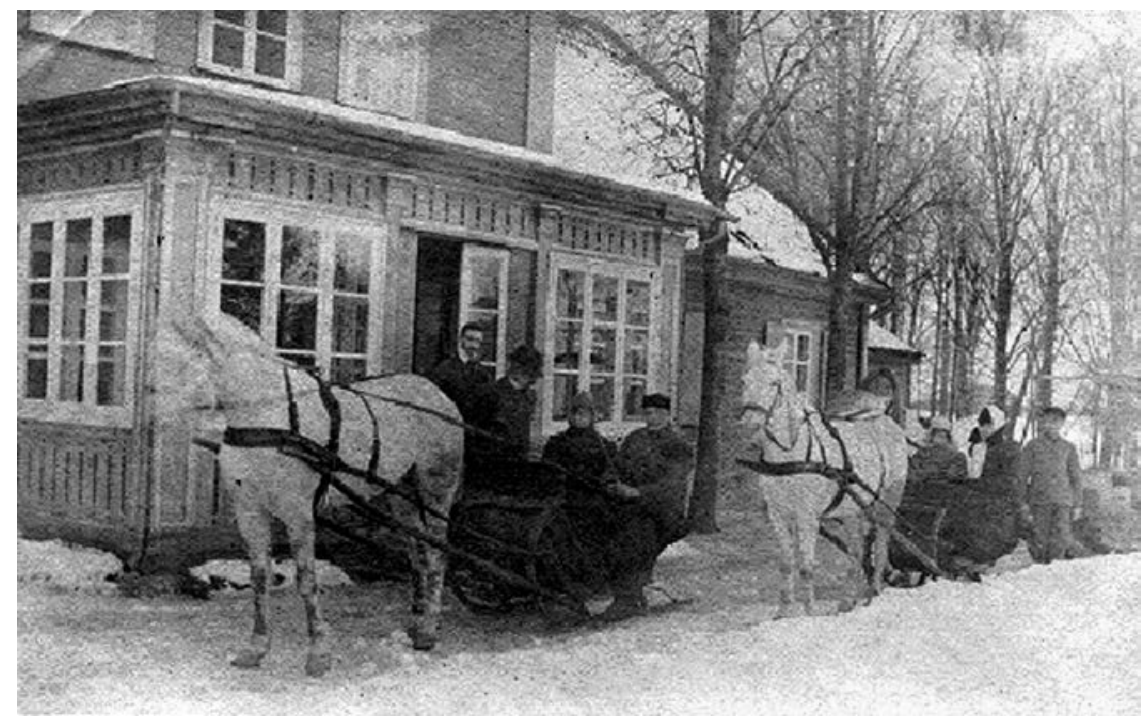

Ponų namo (A-1) su uždaru, ịstiklintu prieangiu detalè žiemą, apie 1910, Johano Grothuso nuotrauka
Detail of the master's house (A-1) with a closed glassed porch in winter, ca. 1910

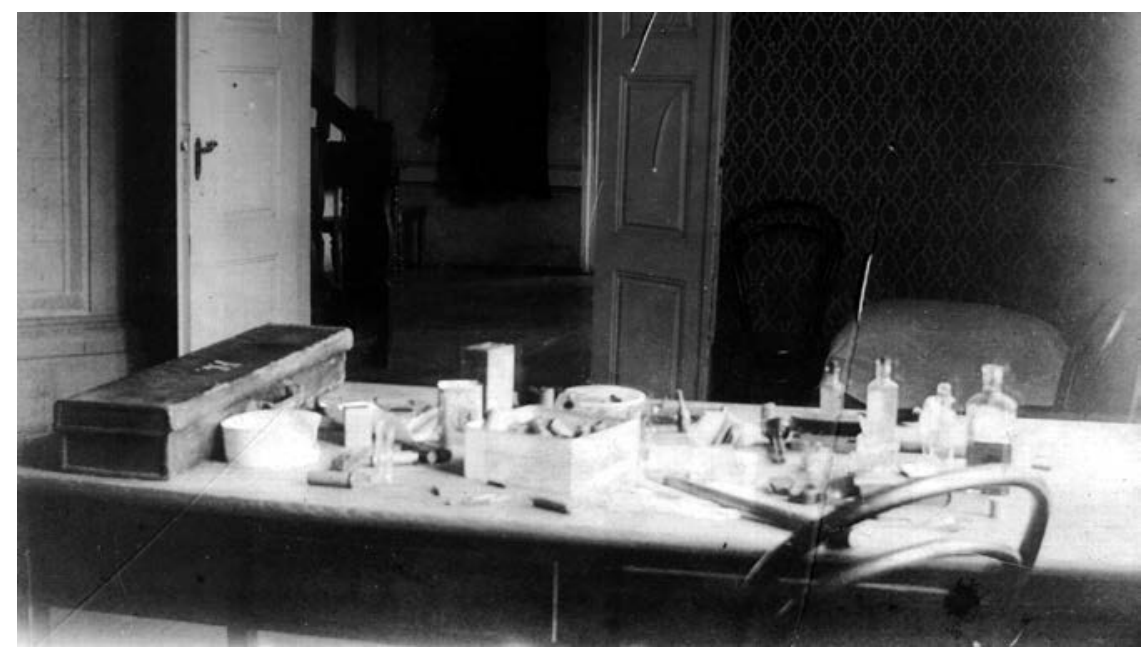

9.

Vaikų kambarys, apie 1910, Johano Grothuso nuotrauka Nursery ca. 1910 


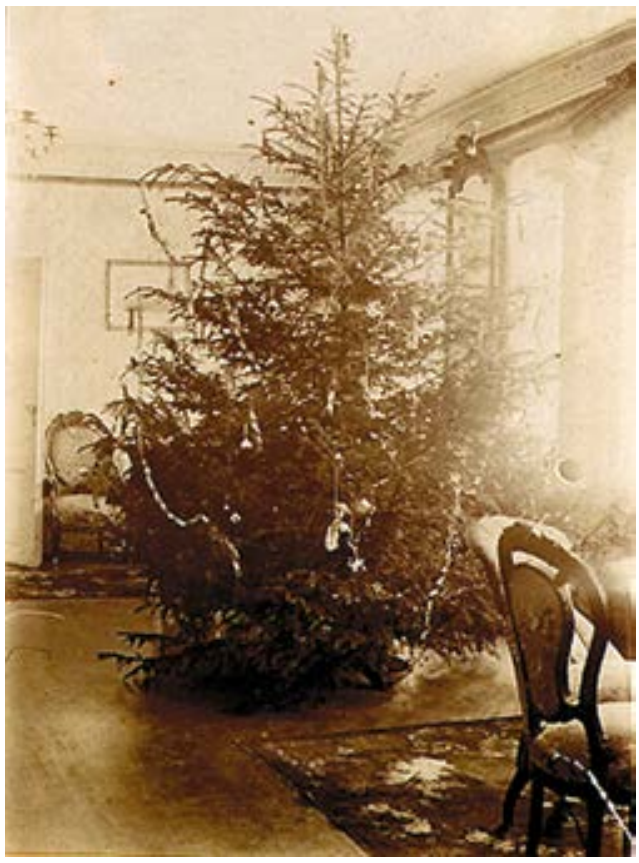

10.

Kalėdinė eglutė svetainėje, apie 1910, Johano Grothuso nuotrauka

Christmas tree in the living room ca. 1910

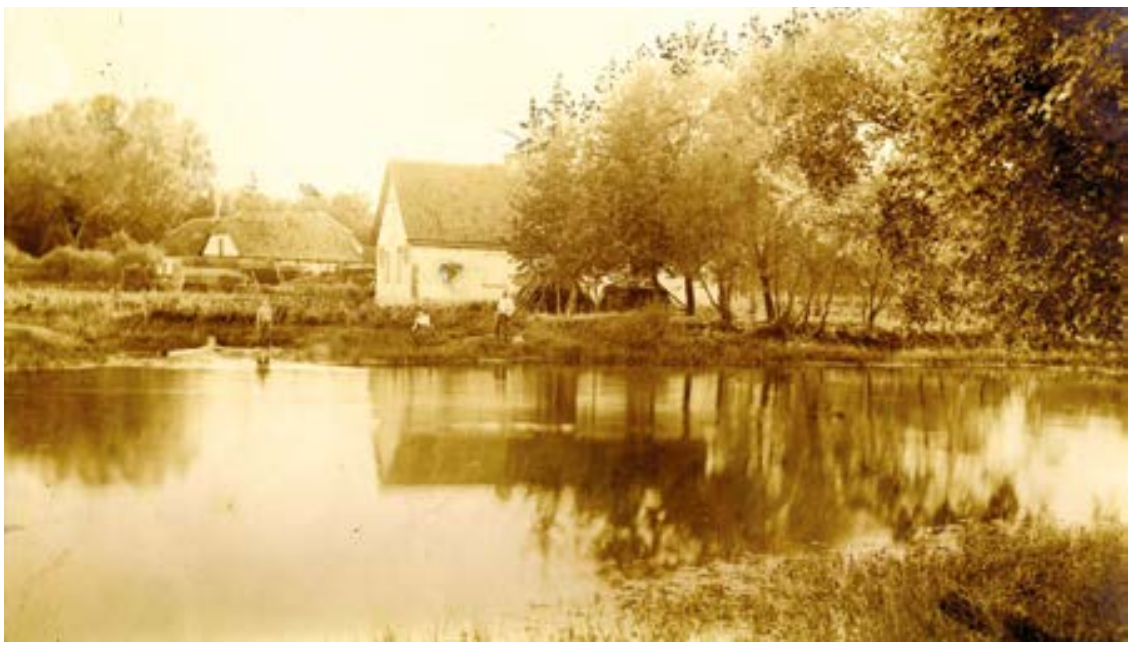

11.

Kūdra ir kumetynas (A-11), apie 1910, Johano Grothuso nuotrauka
Pond and farmhands' house (A-11) ca. 1910 
1928 m. Lieporų dvaro sodyboje išvardytijau 27 trobesiai (kai kurie buvę perstatyti; daug kur nurodyta statybinė medžiaga - mūras, kurị reiktų suprasti kaip molį). Minima ir sodyba, vadinama „Frankyne“ (buv. karčema, 4 trobesiai), kurioje veikè Kriukų pieno perdirbimo bendrovès pieninè ${ }^{80}$. 1929 m. sudarytame plane nurodoma, kad dvaro sodyba užėmė 6,34 ha plotą ${ }^{81}$. Albertiškių palivarke išvardyti 9 trobesiai, Karklynės - 8, Miežinių - 3 . Aprašytas ir nusavintų palivarkų bei vienkiemių 2 ha dydžio sodas: 119 obelų, 4 kriaušès, 9 vyšnios ir slyvos, 49 laukiniai medžiai ${ }^{82}$.

\section{4 lentelè. Buvusio Lieporų (Grothusų) dvaro, palivarkų pastatų suvestinè $1928 \mathrm{~m}^{83}$}

\begin{tabular}{|c|c|c|c|c|c|c|c|c|}
\hline Eilès Nr. & Trobesys & Ilgis & Plotis & $\begin{array}{l}\text { Aukštis su } \\
\text { pamatais }\end{array}$ & $\begin{array}{l}\text { Aukštis } \\
\text { be } \\
\text { pamatų }\end{array}$ & Sienos & Stogas & Būklè \\
\hline \multicolumn{2}{|c|}{ Liepory̨ dvaras } & \multicolumn{4}{|c|}{ Metrai } & \multicolumn{3}{|l|}{ Medžiagos } \\
\hline 1. & \begin{tabular}{|l|} 
ponų \\
namas
\end{tabular} & 37 & 12,5 & 3,4 & 2,9 & medis & $\begin{array}{l}\text { čerpių ir } \\
\text { skardos }\end{array}$ & gera \\
\hline 2. & svirnas & 19 & 8,26 & 33,3 & 2,55 & \begin{tabular}{|l|} 
mūro / \\
molio
\end{tabular} & čerpių & vid. \\
\hline 3. & pirtis & 7 & 3,9 & 2,2 & 2 & medžio & čerpių & vid. \\
\hline 4. & daržinè & 26 & 11 & 3,3 & & ant stulpu & gontų & vid. \\
\hline 5. & daržinè & 26 & 11 & 3,2 & & ant stulpu & šiaudų & sena \\
\hline 6. & daržinè & 53,5 & 11,3 & 4 & & \begin{tabular}{|l|} 
mūro / \\
molio
\end{tabular} & gontų & patenk. \\
\hline 7. & kumetynas & 10,75 & 7 & 2,7 & 1,9 & $\begin{array}{l}\text { mūro / } \\
\text { molio }\end{array}$ & čerpių & patenk. \\
\hline 8. & tvartas & 15,2 & 4,2 & 2,4 & 1,9 & $\begin{array}{l}\text { mūro / } \\
\text { molio }\end{array}$ & šiaudụ & patenk. \\
\hline 9. & kalvè & 14,7 & 8,4 & 3 & 2,25 & \begin{tabular}{|l} 
mūro / \\
molio
\end{tabular} & čerpių & patenk. \\
\hline 10. & kumetynas & 33 & 8,6 & 3 & 2,5 & $\begin{array}{l}\text { mūro / } \\
\text { molio }\end{array}$ & čerpių & patenk. \\
\hline 11. & tvartas & 24,8 & 10 & 2,85 & 2 & $\begin{array}{l}\text { mūro / } \\
\text { molio }\end{array}$ & gontų & patenk. \\
\hline 12. & svirnas & 16,2 & 9,5 & 2,2 & 2,1 & $\begin{array}{l}\text { plytų ir } \\
\text { mūro }\end{array}$ & gontų & patenk. \\
\hline 13. & vežiminè & 31,1 & 7,95 & 3,25 & 3 & $\begin{array}{l}1 / 2 \text { mūro, } \\
1 / 2 \text { lentụ }\end{array}$ & gontų & patenk. \\
\hline 14. & karvidè & 50 & 13 & 3 & 2,1 & $\begin{array}{l}\text { mūro / } \\
\text { molio }\end{array}$ & gontų & patenk. \\
\hline
\end{tabular}

80 Op. cit., in: LCVA, f. 1248, ap. 2, b. 1844, l. 18-19.

81 Kriukų vls. Lieporių dv. 1. Dvaro, Albertiškių ir Miežinių palivarkų parceliacijos planas (1:5000), 1929, in: LCVA, f. 1250, ap. 4, b. 13/261, l. 1.

82 Lieporiu dvaras, in: LCVA, f. 1248, ap. 20, b. 2226, 1. 4-5, 50, 93-94.

83 Sudaryta pagal: op. cit., in: LCVA, f. 1248, ap. 2, b. 1844, 1. 19, 22, 25, 28; op. cit., in: LCVA, f. 1248 , ap. 20 , b. 2226 , l. $3,5,24,50$. 


\begin{tabular}{|c|c|c|c|c|c|c|c|c|}
\hline 15. & tvartas & 22,5 & 9 & 2,8 & 2 & $\begin{array}{l}\text { mūro / } \\
\text { molio }\end{array}$ & gontų & patenk. \\
\hline 16. & arklidè & 22,5 & 9 & 3 & 2,5 & $\begin{array}{l}\text { mūro / } \\
\text { molio }\end{array}$ & gontų & patenk. \\
\hline 17. & $\begin{array}{l}\text { malkų } \\
\text { daržinè }\end{array}$ & 12,5 & 7,5 & 2,7 & & lentụ & gontų & patenk. \\
\hline 18. & daržinè & 17 & 9,3 & 3 & 2,8 & lentụ & gontų & patenk. \\
\hline \multicolumn{9}{|c|}{ Frankynès vienkiemis (buv. karčema) } \\
\hline 19. & pieninè & 23,5 & 9,5 & 3,2 & 2,7 & $\begin{array}{l}\text { mūro / } \\
\text { molio }\end{array}$ & čerpių & patenk. \\
\hline 20. & tvartas & 20 & 7 & 3,1 & 2,5 & plytų & čerpių & patenk. \\
\hline 21. & $\begin{array}{l}\text { gyvenama- } \\
\text { sis namas }\end{array}$ & 14 & 7,5 & 3 & 2,7 & $\begin{array}{l}\text { mūro / } \\
\text { molio }\end{array}$ & gontų & patenk. \\
\hline 22. & $\begin{array}{l}\text { tvartas su } \\
\text { daržine }\end{array}$ & 16 & 6 & 3 & 2 & $\begin{array}{l}\text { 1/2 plytų, } \\
1 / 2 \text { lentų }\end{array}$ & gontų & patenk. \\
\hline 23. & $\begin{array}{l}\text { gyvenama- } \\
\text { sis namas }\end{array}$ & 23,5 & 11 & 3 & 2,7 & $\begin{array}{l}\text { mūro / } \\
\text { molio }\end{array}$ & čerpių & patenk. \\
\hline 24. & svirnas & 15 & 6,5 & 2 & & medžio & šiaudụ & patenk. \\
\hline 25. & $\begin{array}{l}\text { klojimas su } \\
\text { daržine }\end{array}$ & 21 & 7 & 3,3 & 3,1 & $\begin{array}{l}\text { mūro / } \\
\text { molio ir } \\
\text { medžio }\end{array}$ & šiaudụ & sena \\
\hline 26. & tvartas & 29 & 7,5 & 3,2 & 2,6 & $\begin{array}{l}\text { mūro / } \\
\text { molio }\end{array}$ & šiaudụ & sena \\
\hline 27. & daržinè & 26,5 & 9 & 3 & & ant stulpų & šiaudų & sena \\
\hline \multicolumn{9}{|c|}{ Albertiškių palivarkas } \\
\hline 1. & daržinè & 27,5 & 12 & 4 & 3,5 & ant stulpų & šiaudų & patenk. \\
\hline 2. & klojimas & 31,25 & 9,25 & 4 & & molio & gontų & gera \\
\hline 3. & gyv. namas & 15 & 8 & 2,8 & 2,5 & molio & čerpių & patenk. \\
\hline 4. & $\begin{array}{l}\text { klètis su } \\
\text { vežimine }\end{array}$ & 18 & 9 & 2,4 & 2 & molio & gontų & patenk. \\
\hline 5. & daržinè & 12,25 & 7,25 & 2,8 & 2,5 & molio & gontų & patenk. \\
\hline 6. & tvartas & 22,2 & 9 & 3,5 & 3 & molio & gontų & patenk. \\
\hline 7. & tvartas & 12,3 & 7 & 2 & 2 & molio & gontų & sena \\
\hline 8. & tvartas & 22 & 7,25 & 2,4 & 2 & molio & šiaudų & sena \\
\hline 9. & gyv. namas & 12,25 & 7,25 & 2,6 & 2,3 & molio & čerpių & sena \\
\hline \multicolumn{9}{|c|}{ Karklynès (Ožolynès) palivarkas } \\
\hline 1. & gyv. namas & 15,4 & 7,5 & 2,9 & 2,4 & molio & gontų & sena \\
\hline 2. & $\begin{array}{l}\text { klètis su } \\
\text { vežimine }\end{array}$ & 22 & 8 & 2,8 & 2,5 & molio & gontų & patenk. \\
\hline 3. & klojimas & 24 & 7,3 & 3,5 & 3 & molio & šiaudų & patenk. \\
\hline 4. & $\begin{array}{l}\text { daržinè } \\
\text { javams }\end{array}$ & 26 & 10 & 3,4 & 3 & ant stulpų & šiaudụ & patenk. \\
\hline 5. & $\begin{array}{l}\text { tvartas su } \\
\text { daržine }\end{array}$ & 22 & 6 & 2,7 & 2,5 & $\begin{array}{l}\text { molio, ant } \\
\text { stulpy }\end{array}$ & šiaudu & patenk. \\
\hline 6. & gyv. namas & 21,8 & 7,3 & 2,5 & 2,2 & medžio & šiaudų & sena \\
\hline 7. & pirtis & 6 & 4,5 & 2 & & medžio & čerpių & sena \\
\hline 8. & tvartas & 42,8 & 9 & 3,4 & 3 & molio & šiaudụ & patenk. \\
\hline \multicolumn{9}{|c|}{ Miežinių palivarkas } \\
\hline 1. & gyv. namas & 18 & 7 & 22 & 2 & medžio & gontų & patenk. \\
\hline 2. & $\begin{array}{l}\text { tvartas su } \\
\text { daržine }\end{array}$ & 15 & 6,25 & 2,5 & 2 & $\begin{array}{l}\text { mūro / } \\
\text { molio ir } \\
\text { medžio }\end{array}$ & be stogo & patenk. \\
\hline 3. & $\begin{array}{l}\text { klètis su } \\
\text { vežimine }\end{array}$ & 18 & 7 & 2,2 & 2 & $\begin{array}{l}\text { mūro / } \\
\text { molio }\end{array}$ & gontų & patenk. \\
\hline
\end{tabular}




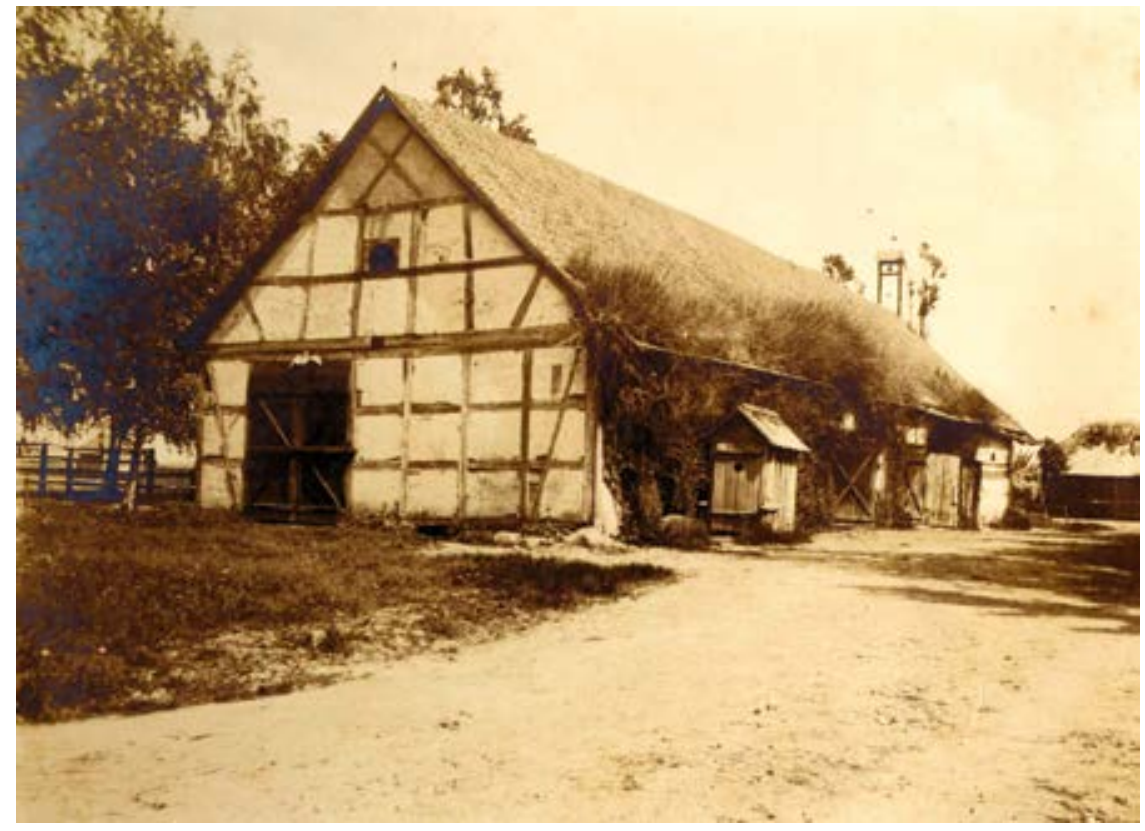

12.

Fachverkinè vežiminè $(1928$ / 13) su tualetu, Johano Fachwerk carriage house (1928 / 13) with a toilet Grothuso nuotrauka

Geriausiai dokumentuota baronų Grothusų valdymo laikotarpio (1826/1834-1940) Lieporų dvaro sodybos struktūra. Ji, kaip matyti iš kartografinès medžiagos, buvo netaisyklingos trapecijos formos, paveldèta iš XVII a. pabaigos - XVIII a., barokinių bruožų - aplink atvirą stačiakampi kiemą šiaurinėje sodybos dalyje išdèstyti trobesiai, kurie buvę statyti klasicizmo ir istorizmo laikotarpiais, dalis jų fachverko konstrukcijos. Ja XIX a. - 1940 m., kaip ir kitas regiono vidutinių valdų dvarų sodybas, sudarė 4 dalys: 1) reprezentacinis kiemas (su ponų namu, svirnu daiktams, prievaizdo namu-oficina, kumetynu ir klomba viduryje - naujas klasicizmo elementas); 2) greta prigludęs ūkinis (tvartų) su svirnu kiemas; 3) atokiau, i šiaurès rytus, buvo gamybinè zona su kalve; 4) i rytus - kluoniena. Greta ūkinio kiemo, pietinejje pusėje, buvo ịrengtas šakniavaisių daržas. Sodybą iš pietų supo landšaftinis parkas su sodu, rytinèje pusėje buvo iškastos kūdros ir pirtis, iš viso 15-27 trobesiai. Parke atskirai buvo numatytos vietos 
aviliams, šunims ir arkliams laidoti, kūdrose plaukiojo vandens paukščiai (greta buvo paukštidè). I sodybą buvo patenkama keliu, ejjusiu nuo KriukųŽeimelio vieškelio link Juodeikių dvaro, iš šiaurès vakarų pusės per šiaurinèje pusèje pasodintą beržų alèją.

Duomenu apie dvaro sodybos trobesių statybos datas nèra. 1894 m. bylos lentelès „Pastatų aprašymas ir vertë“ grafoje „Egzistavimo laikas ir būklë“ nurodomos 3 būklès - tvirtas (dauguma), senas (klojimas) ir naujas (2 daržinès laukuose). Ponų namas, kaip ir kiti trobesiai, matyt, statyti XIX a. pirmoje pusėje, kai formavosi Lieporų atšakos baronų Grothusu rezidencija. Apie tai užsimenama ir Aleksandro atsiminimuose:

Kambarių išdėstymas ponų name buvo maždaug toks kaip Frico [Otto Ewald Friedrich (1774-1848)] ir Mausen laikais, tik kambarius reikia įsivaizduoti ir mezonine, nes jis buvo pastatytas Frico, taip pat ir priestatas virtuvės pusėje. Seniau virtuvès priestatas buvo toks pat kaip ir kitame gale. ${ }^{84}$

Taigi ponų namas priskirtinas vėlyvojo klasicizmo laikotarpiui, kiti trobesiai - istorizmo. Jų statybai naudotos Kuršui ir Žiemgalai būdingos tradicinès medžiagos - medis, molis (akmenų laukuose, kaip pažymima $1894 \mathrm{~m}$. byloje, trūko) bei technologijos - dažnai fachverko konstrukcija (ištisai arba skyduose) ir kt. Tai priskiriama vadinamajam „senajam vokiečių Baltijos stiliui“" (vok. Altbaltisches Herrenhaus, angl. Old Baltic type). Išlikusiame Grothusų šeimos archyve užfiksuoti dvaro sodybos trobesiai, ponų namo interjeras, želdiniai, o A. Grothuso ir M. Vanagos atsiminimuose aprašyti ponų namas bei parkas. Tiesa, Gerardo Bagdonavičiaus (1901-1986) ekspedicija, atlikusi dvarų meno vertybių ir bibliotekų inventorizaciją Joniškio krašte, 1940 m. rugpjūčio 29 d. dvare nieko vertingo (minimo M. Vanagos) neaptiko:

Iš Paudruvės pro Kriukus į Vengriškių dvar. Mat senis latvis papasakojo, kad tenai galim rasti gal ką nors ir geresnio. Bet pasirodo, kad <...> nusigyvenęs iš kilmès Baronas. Visi geresnès vertės daiktai per apsileidimą nusigyvenimą yra išnykę. Iš čia ị Lieporų dvar. Paties savininko nėra. Jis Klaipėdoje dabar gyvena. Čia vieną 


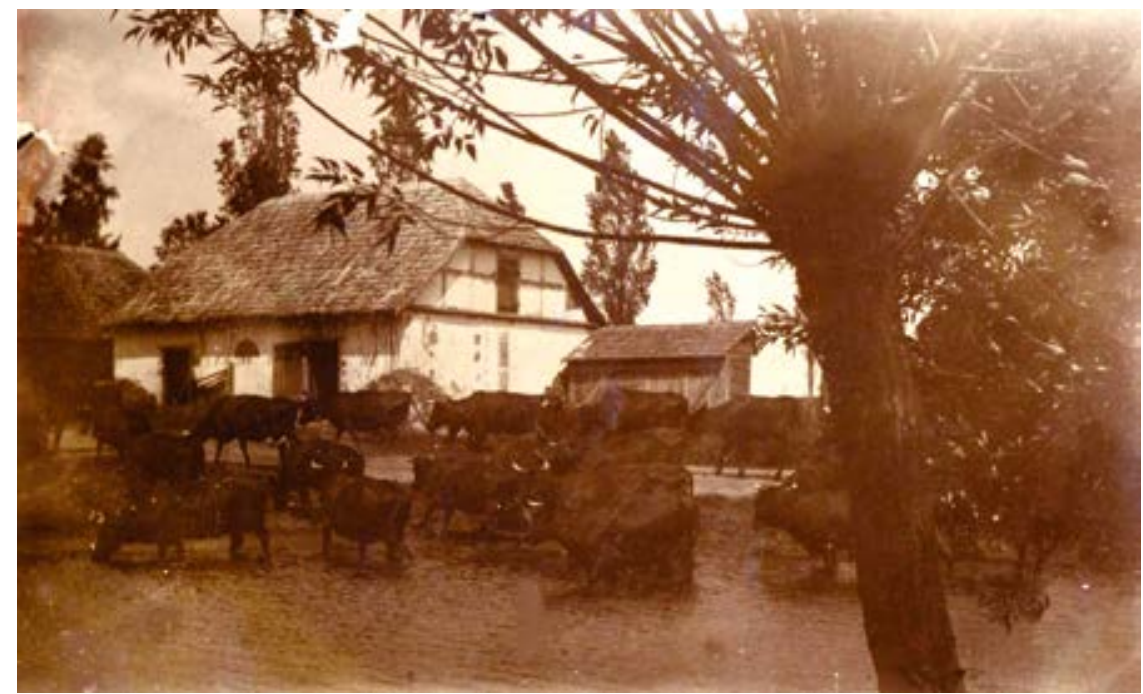

13.

Galvijai, kumečiu molinis tvartas (A-9), kūdra, Johano Cattle, farmhands' clay cattle-shed (A-9), pond Grothuso nuotrauka

kitą daiktelį radom, bet neregistravom, nes tų daiktų savininkė yra dail. Grotosienè $^{85}$, kuri rodos dalyvavo ir Kaune parodose kaip mūsų dailininkè. Ant spintos radome keletą ir jos pačios darbų: natiurmortų ir keletą portretų. ${ }^{86}$

Nacionalizavus dvarą $1941 \mathrm{~m}$. jis buvo perduotas „Taikos“ kolūkiui. Ponų name, kumetynuose apsigyveno keletas šeimų, svirne ịrengtas kolūkio sandèlis, kalvė naudota pagal paskirtị. Prasidejjo sodybos nykimas: vieni pastatai sudegė (1944 m. rugpjūčio mèn. aeronuotraukoje matyti jau sudegę arklidè, tvartai, o buvęs ponų namas sudegè 1957 m.) [14 il.], kiti

85 Turima omeny Johano pirmosios žmonos dailininkès Benitos (Benita geb. von Behr, *1892 07 10, Palanga, †1976 09 11, Schliersee; susituokė Liepojoje 1919 m., išsiskyrė Kaune 194008 14) darbai. B. Grothus prieš Pirmajji pasaulinị karą mokèsi Peterburgo dailès akademijos Rygos dailès mokykloje, rengusioje piešimo mokytojus, prasidejus karui diplomo negavo, 1938 m. isstojo laisvaja klausytoja į KMM, aliejumi ir tempera nutapė peizažų, portretų (Ponia H., V. Butlerio portretas, Mergaite švedišku kostiumu ir kt.), dalyvavo dviejose Lietuvos dailès draugijos sajungos parodose (Lietuvos dailininku žodynas, t. III: 1918-1944, sud. L. Šatavičiūtè-Natalevičienė, Vilnius: Lietuvos kultūros tyrimų institutas, 2013, p. 68; III rudens dailès paroda: Kaunas 1937 m. gruodžio mèn. 19 d. - 1938 m. sausio mèn. 16 d., Kaunas: Vytauto Didžiojo kultūros muziejus, [1937], p. 7). Piešinių albumas, atliktų pirmosios Frydricho Grothuso žmonos Karolinos (Caroline (Ina) geb. von Behr, 1854-1881) tušu ir pieštuku, saugomas M. Grothuso archyve.

86 [Jankus, Gerardas Bagdonavičius, Šiaulių apskr. dvarų inventorizacija, Šiauliai, 1940], in: Kultūros paveldo centras, f. 17, ap. 2, b. 11, 1. 14-15. 


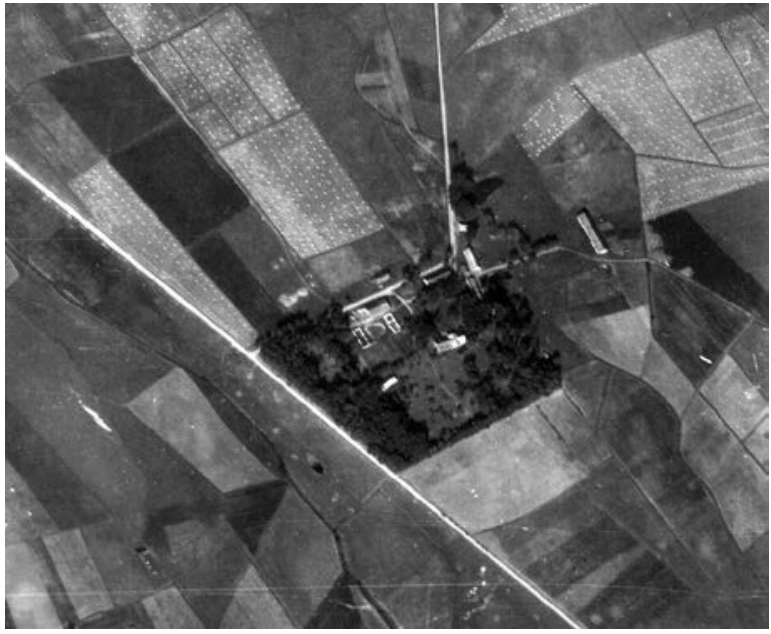

14.

Lieporų dvaro sodyba.

Vakaruose - tiesinta Lieporo upelio vaga, rytuose - klojimas, 194408 20, LCVA, NARA, RG 373 GX2685B, Nr. 345

Lieporai Manor. In the west the straightened bed of the Lieporas rivulet, in the east a barn

sugriuvo arba buvo nugriauti, kūdros užlygintos. Dabar iš buvusios Lieporų dvaro sodybos išliko tik apleistas savaiminiais medžiais apaugęs parkas, kuris oficialiuose dokumentuose figūruoja kaip miškas.

\section{Apibendrinimas}

Istorinès Žiemgalos teritorijos dvarų atsiradimas ir raida kol kas menkai tyrinėti. Ir dèl Lieporų dvaro pradžios, kaip ir daugelio kitų rašytinių šaltinių ir archeologinių duomenų, stokojama medžiagos. Tikètina, Lieporų laukas (XV-XVI a.) susiformavo XIII a. buvusios žiemgalių apygardos (Rytų Žiemgalos - Upmalès) pagrindu. Valda, pasibaigus Livonijos karui ir 1583-1586 m. atlikus Livonijos ir LDK sienų korekciją, perėjo LDK Upytès valsčiui (pavietui). Lieporų dvaro (Żybort mö̈ża/mü̈ża) įkūrimo data tuometinèje Livonijos ordino teritorijoje laikomi 1539 m., iki 1676 m. su pertraukomis buvo valdytas Livonijos ordino vasalų vietos (žiemgalių (?)) kilmės bajorų Druvių, po jų - baronų Frankų 1666/1676-1826/1834 m., laikinai Tyzenhausu - 1763-1773 m. ir galiausiai 1826/1834-1940 m. - Grothusų. Frydrichas Grothusas (1774-1848, Berstelès linija) tarp 1826-1834 m. ịsigijo Lieporų dvarą, ir yra laikomas šios atšakos pradininku.

Valdant baronams Frankams, apie 1775 m., Lieporų (Karklien) ir Lieporų-Albertiškių dvarai buvo sujungti ị vieną valdą. Lieporų valdą 
1775-1861 m. sudarè 1037 dešimtinès su 18-26 dūmais, 1878 m. - 400 dešimtinių, iki 1922 m. - 429,51 ha. Po 1922 m. žemès reformos palikta nenusavinta 151 ha valda. Lieporai iki valstiečių reformos $1861 \mathrm{~m}$. priskirtini prie vidutiniu dvarų. Lyginant ji su kitais dabartinio Joniškio r. teritorijos vokiečių kilmingujų dvarais (susiję tiek giminystės ryšiais, tiek nuosavybės) matyti ir skirtumų: Daunoravos dvare dūmai (ūkiai) buvo gerokai didesni (gyveno vidutiniškai apie 15-16 žmonių), o Malgūžès - ūkių dydžiai buvo panašūs ị Lieporų dvaro.

Geriausiai dokumentuota Grothusų valdymo laikotarpio Lieporų dvaro sodyba, kurios struktūra paveldèta iš senesnių laikų (XVII a. pabaigos - XVIII a.) su barokiniais bruožais - aplink atvirą kiemą išdèstyti trobesiai, kurie buvę statyti vèliau (priskiriami klasicizmui ir istorizmui). XIX a. - 1940 m. susiformavusią dvaro sodybą sudarė 15-27 trobesiai, su reprezentaciniu ir ūkiniais kiemais, gamybine zona (kalve), kluoniena, peizažiniu parku ir sodu, kūdromis.

\section{Atsiminimai}

\section{Lieporų ir Misos dvarai}

Aleksandras Grothusas glaustai aprašė Lieporų ir Misos (valdytas tèvo brolio) dvarus, ponų namo suplanavimą, interjerą, medžioklès šautuvų kolekciją:

Ponas Bachas (Bach), kaip ir jo protèviai Martinas (Martin) ir Biokeris (Böhker), gyveno oficinoje (jos gale vèliau gyveno prievaizdas Karlas), kur tuomet buvo du kambariai: vienas iš jų buvo mokytojo miegamasis, o kitas atliko gyvenamosios patalpos ir mokyklos klasės funkciją. Kambariai ponų name buvo išdėstyti panašiai kaip Frico [Otto Ewald Friedrich von Grotthuss (1774-1848), Aleksandro senelis $\uparrow$ ] ir Mausen laikais, dar kambariu buvo ir mezonine, kuris buvo pastatytas Frico, taip pat ir priestatas virtuvės pusėje. Seniau virtuvės priestatas buvo toks pat kaip ir kitame gale.

Vaikų kambarys buvo Dartès (senos latvès auklès Behrsche, atvykusios kartu su senele (Mausen [Juliane Wilhelmine von Vic (1780-1850)], 


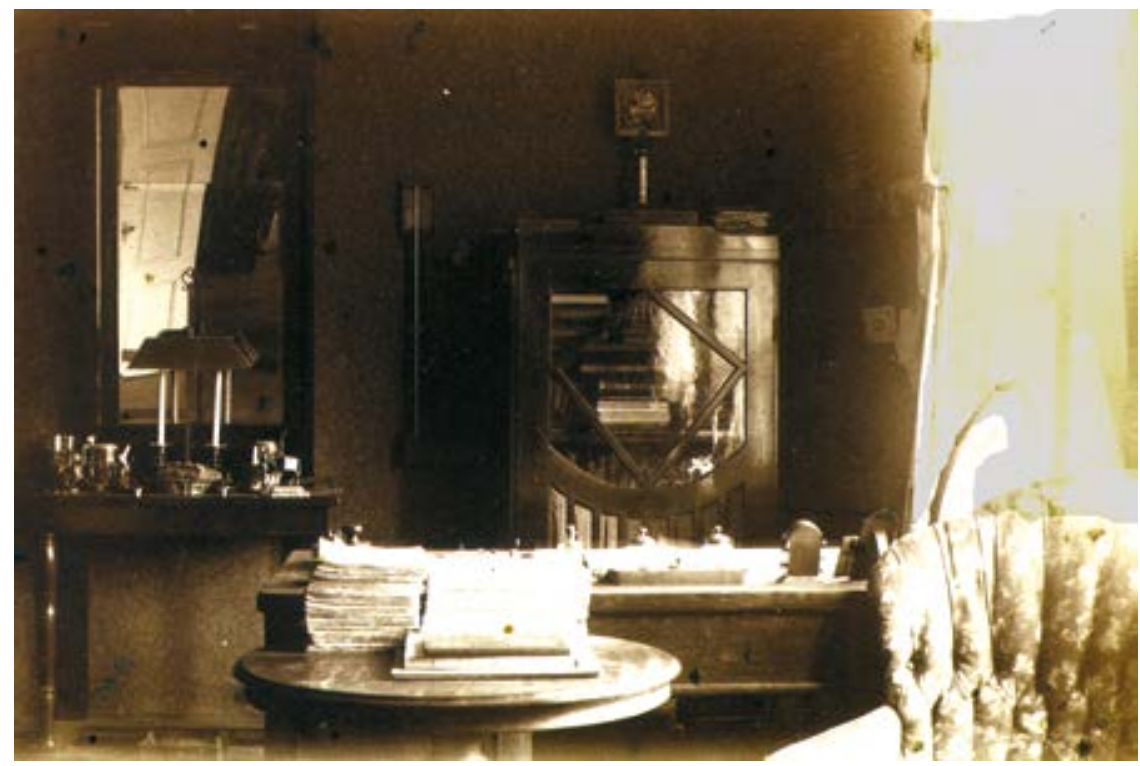

15.

Barono darbo kambarys, apie 1910, Johano Grothuso ～Baron's office ca. 1910 nuotrauka

kuri ištekẻjusi atvyko ị Lieporų dvarą) kambarys. Dabartinejje kamarèlëje gyveno teta Olga. Mausen miegamasis buvo mano mamos drabužinė, tamsusis kambarys - tèvų miegamasis. Frico miegamajame, iš kurio mažos, o ne didelès, durys (jos, beje, buvo paslëptos už spintos) vedẻ iš tamsiojo kambario ị Hanso kabinetą, gyveno mano senelis Villebois. Hanso kabinetas [15 il.], iš kurio per dideles duris buvo patenkama ị senelio kambari, buvo mano tèvo drabužinė, Fricas ten ir miegojo. Kaimynais tuomet buvo Strombergai Sesavoje (Krons-Sessau), Brašai (von Brasch) - Brašo Lieporu dvare (Brasch-Leeparn), Keizerlingai (Keyserlingk) - Malgūžès dvare (Malguschen). Pono Strombergo (Paul), jeigu neklystu, ankstesnio kaimyno iš Apguldès (Abgulden), brolis buvo vedęs Mariją (Marie geb. von Goes) iš Variebos (Warriben, visi Latvijoje). Vèliau jie išsiskyrè.

Dar kartą apie senaji Fricą [Heinrich Friedrich Theodor von Grotthuss, 1805-1871, Frydricho sūnus]. Misoje (Misshof, dab. Dzimtmisa, Latvija) su dėde aš lankiausi dar vaikystėje. Ponų namas buvo ilgas, vienaukštis, 
medinis, didesnis nei Lieporų dvaro ir iš dalies apstatytas baldais. Didelè dalis baldų buvo atvežta dėdès Theodoro [Gotthard Ludwig Theodor von Grotthuss, 1811-1893, Frydricho sūnus $\uparrow]$ iš Paryžiaus, kur jis kartu su šeima ilgą laiką gyveno pas savo broli. Dėdè Fricas nebuvo išrankus, jo namuose buvo visa, kas reikalinga. Visur buvo galima pastebèti, kad jis medžiotojas: stalas su briedžio kojomis, ginklų spinta. Prieškambaryje aptraukta sofa buvo skirta šunims. Medžiokliniai šautuvai, labai daug šautuvų kabojo prieškambaryje, o brangūs ginklai buvo spintoje. Koks šiu pakabintų ginklų vaidmuo, man buvo neaišku, vẻliau jų nebeliko. $1864 \mathrm{~m}$. mano dėdẻ buvo užpultas banditų gaujos ir apiplèštas. Sidabras, žiedai, laikrodžiai ir pinigai, kuriuos jis laikè artejjančiam kredito terminui Kuršo kredito unijai sumokèti, taip pat ir medžiokliniai šautuvai iš prieškambario ir ginklai iš kitų kambarių buvo pagrobti. Išliko tik tie, kurie buvo ginklų spintoje, nes dėdei pavyko banditus apgauti pasakius, kad ši spinta su nepermatomu stiklu yra jo vaistų spinta. Lefaucheux karabinas, ilgai priklausęs Fricui, taip pat buvo šioje spintoje ${ }^{87}$.

Lieporų dvaro prievaizdo šeimoje gimė Aleksandras Vanagas (Aleksandrs Vanags, 1907-1942, sušaudytas Sverdlovske) - latvių žurnalistas, Daugavas Vēstnesis (Dauguvos žinios) vyr. redaktorius, Brīva Zeme (Laisva žemè) redakcinès kolegijos narys. Jo žmona - teisininkè, žurnalistè, rašytoja Melanija Vanaga (1905-1997) savo autobiografijoje, kultūros istorijos septimologijos Dvēseļu pulcēšanas (Sielu susirinkimas) 5-oje knygoje Iedzīvoju pasakā (Gyvenu pasaka, 1997) aprašè atsiminimus, ìspūdžius ir išgirstas istorijas iš pirmosios kelionès i vyro gimtinę - Lieporų dvarą $1931 \mathrm{~m}$. per Kalèdas ${ }^{88}$. Šie atsiminimai priskirtini pasakojamosios istorijos žanrui, kur neišvengta ir klaidų, pavyzdžiui, teksto dalis, kurioje kalbama apie Lieporų dvaro pavadinimo kilmę (žinomas jau nuo XVI a. $\uparrow$ ), Grothusu protėvius Budbergèje (ši dvarą valdè ne protèviai, bet jų giminaičiai), - tad ji vertintina kritiškai. Čia, matyt, suplaktos kelios versijos - girdètos Lieporuose ir vėliau kažkur Latvijoje. Nežiūrint to, tai yra ịdomus XX a. 4 deš. užfiksuotas vieno krašto dvaro ir Grothusų istorinès atminties bei kasdieninio gyvenimo pavyzdys.

87 [Grotthuss Alexander], op. cit., p. 19, 46-47. Iš vokiečių kalbos vertė Vilija BavarskytèHandschin, redagavo Ernestas Vasiliauskas.

88 Sigurds Rusmanis, Zeme starp Rundāli un Tèrveti, Rīga: Jumava, 2006, p. 29-31. 


\section{Gedertas Sūrumas}

Lieporai, kaip jau rašyta, buvo naujas pavadinimas senajam Grothusu dvarui, kurio pavadinimą apylinkėse minėdavo ne ypač palankiai. Šio dvaro žmonès net vengė ir nepageidavo ten tarnauti. Tačiau jauniesiems Sūrumams visas pasaulis atrodè kaip laimès sala, ant kurios net medžiai nemetè šešèlio.

Ir jaunieji dvaro baronai buvo geresni, nors ir turejjo tą pačią blogai pagarsèjusią Grothusų pavardę. Tie blogieji buvo Grothusų protèviai, apie kuriuos pasakoja šiurpias legendas. Jie buvo tiek mokslininkai, tiek žiaurūs dvarininkai.

Senieji Grothusai kadaise gyveno dvare prie Nemunèlio, kur viena šalia kitos itteka daugybè upelių. Šią vietą apie senają Budbergę $e^{89}$ dar ir dabar vadina Devinšake. Senasis Grothusas buvo siaubingas, iš dvaro žmonės bėgo kaip velnio apsèsti. Kai kurie tarnai buvo linkę pasitraukti iš gyvenimo, nei likti amžinoms kančioms pas tokị poną.

Ne ką geresnè buvo ir senoji baronienè. Vasaromis važiuodavo ị Nemunèli maudytis su dvaro mergomis įkinkyta karieta ir jas mušdavusi skaudžiau nei vežėjas arklius. Kartą mergos susitarė, kad šioms kančioms reikia padaryti galą. Ir taip važiavo, taip lèkè, kad su visa ponia nuo aukšto kranto ịlèkè akivaran. Vanduo tik sukunkuliavo ir galiausiai žmonėms atejjo ramybė.

Ir pats baronas važinėdavosi po dvaro parką su karieta, kurioje buvo įkinkytos tik dvaro mergos. Siaubūną visi prakeikè, ir galiausiai jị velnias nugalabijo. Kai numirè, tarnai jị surišo virvėmis, kad nesivaidentų dvare. Kad taip buvo iš tiesų, patvirtinta tarybiniais metais išplèštas barono kapas Budbergès kapinaitèse - atidengtame Grothuso karste kūnas iš tiesų buvo supančiotas stora virve.

Šių Grothusų palikuonys senajame dvare nebenorèjo daugiau gyventi ir persikèlè į Lietuvą, kur dvarą netrukus pavadino Lieporais.

Kai ị Lieporus atsikèlè gyventi Sūrumai, dvaro pastatai buvo pliki, be jokios medžio užuovėjos ir grožio. Naujajam sodininkui teko kurti naują pasauli.

89 Iš tiesų tai buvo ne Lieporų atšakos pradininkai, bet giminaičiai Grothusai, nuo 1750 m. valdę Panemunės (Budbergės, vok. Gemauert-Poniemon) dvarą prie Nemunèlio, Brunavos (Brunowiska czyli Poniemunska) parapijoje, buv. Panevėžio apskr. (1921 m. atiteko Latvijai). Antai 1790 m. padūmės tarifuose minimas Kristupo Grothuso (Christoph Otto von Grotthuss, 1737-1799) valdomas Panemunès (Poniemunie) dvaras su kaimais (1893 ha, 24-34 dūmai). Žr.: Op. cit., in: LVIA, f. 11, ap. 1, b. 707 (SA-3370), 1. 18-18v; Biržų, Pabiržès ir Brunavos parapijų žemèlapis, 1812, in: LVIA, f. 525, ap. 8, b. 1582, l. 10; Percy Schroeders, op. cit., p. 18, 69. 


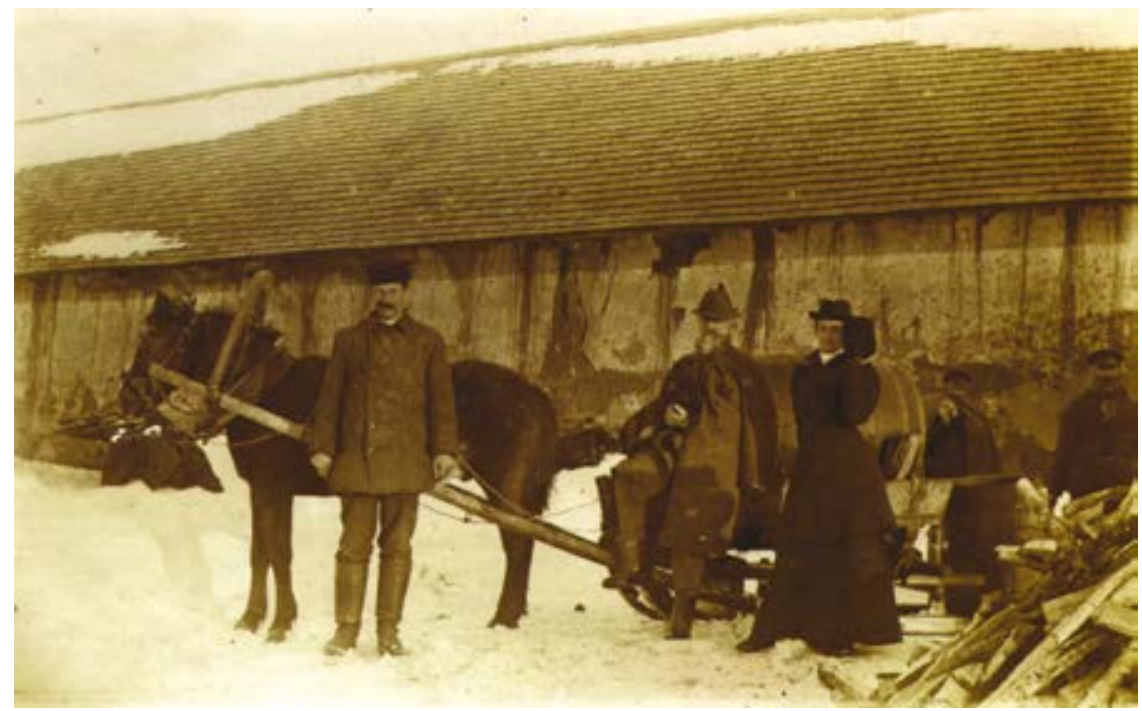

16.

Tvartas su arkliais, prievaizdas Karlas Vanagas (ǐs kairès), baronai Frydrichas ir Marija Gothusai, apie

Cattle-shed with horses, overseer Kārlis Vanags (from 1910, Johano Grothuso nuotrauka

the left), Friedrich and Marie von Grotthuss, ca. 1910

\section{Lieporų dvaras ir jo ponai}

Lieporų dvare pas baronienę kambarine dirbo daržininkų Sūrumų Anelè (Aleksandro mama), o pas baroną prievaizdu - Karlis Vanagas ${ }^{90}$ (Aleksandro tèvas) [16 il.], kurie savo laiku man daug papasakojo apie gyvenimą dvare, kur praejjo visa jų jaunystè. Šviesius atsiminimus apie tą laiką kartu ir apie savo vaikystę išsaugojo ir jų dukra Lekšelio (Aleksandro) sesuo Mildutè (visi ją taip vadino). Būtent Mildutès atsiminimus man lengviausia atpasakoti.

Ponų namas buvo dažytas žalsvai geltonai, dviaukštis medinis namas su keletu verandų ir balkonais. Rūmuose buvo daug kambarių, kuriuose negalėjo būti nė dulkelès. Namuose buvo daug tarnų, kurie diena iš dienos trynè, plovè, blizgino.

Didžiojoje salëje visi baldai buvo su plonomis paauksuotomis kojelèmis. Ant sienų kabojo protėvių portretai ${ }^{91}$, skydai, ietys, kardai. Ant stalo sidabrinès žvakidès ir auksiniai indai gèrimui.

90 Dvaro ịkeitimo Vilniaus valstybės dvarininkų žemės bankui byloje minimas Albertiškių dvaro nuomininkas 1892-1898 m., o anksčiau 24 metų laikotarpiui nuomavęsis ir Miežinių palivarką Jokūbas Vanagas (žr. op. cit., in: LVIA, f. 542, ap. 1, b. 262, l. 7). Išliko ir 1904-1913 m. Albertiškių palivarko nuomos sutartis su J. Vanagu iš Rundalès vls. vokiečių ir vertimas rusų kalba (žr. op. cit., in: LVIA, f. 542, ap. 1, b. 262, 1. 11-16).

91 Veikiausiai turimi omeny Benitos Grothus (Benita von Grotthuss, geb. Behr) darbai. 
Barono kabinete ant sienos kabojo medžiokliniai šautuvai, stirnų ragai ir senujų Grothusų odinis rimbas - tų laikų brangus prisiminimas iš senų ponų neribotos galios laikų. Ant barono rašomojo stalo buvo auksinis varpelis tarnui pakviesti. Ponas savo kabinete priimdavo dvaro valdytoją, eigulius, teisėjus, bažnyčios seniūnus, įvairių amatų meistrus, su kitais bendraudavo valstiečių kambaryje. Tokių nebuvo daug. Be didelio reikalo darbininkas ar valstietis pas poną neidavo.

Kas buvo baronienės ar jaunu̧jų panelių buduaruose, to niekas gerai neatsimena.

Jei baronas būdavo namuose, rūmų bokštelyje plevėsuodavo balta vèliava su juodu Grothusų šeimos herbu. Jei ponas išvažiuodavo, vẻliavą nuleisdavo. Vèliavą pakeldavo ir nuleisdavo barono pasitikejjimą pelnęs Karlis Vanagas.

Po rūmais buvo vyno, mèsos, pieno ir šakniavaisių rūsiai, be to, ir liaudies rūsys, kur buvo saugomi nuo ponų stalui ruošiamos mèsos atskirti lašiniai - tarnų stalui.

Kokie stalai buvo rūmuose?

I stalas, prie kurio valgė tik ponai.

II stalas, prie kurio valgè dvaro panelès (ekonomès), vaikų auklès, ponų virtuvès šeimininkè, tarnai.

III stalas - dvaro tarnams ir tarnaitėms, kuriems ruošdavo kitoje virtuvėje ir iš tų lašinių, kurie likdavo nuo mėsos ponų stalui.

Prieš rūmus buvo gèlèmis apsodintas kiemas (klomba), rytinėje pusėje kūdra.

Netoli kūdros pakraštyje stovejjo ilgas baltas mūrinis pastatas - dvaro žmonių troba - oficina. Užbėgant įvykiams už akių, reikia pridurti, kas šiame pastate gimè - visi Vanagų vyriausi vaikai, taip pat ir Lekšelis (Aleksandras).

Toliau nuo rūmų ị šiaurę stovejjo dvaro svirnai, tvartai, degtinės varykla ir alaus bravoras, medžioklinių šunų namelis. Kambariniams šunims buvo skirtas ir atskiras kambarys pačiuose rūmuose. Toliau - klojimai. Dvaro parkas buvo didžiulis keturkampis su kaštonų ir liepų alèjomis, su dideliu obelų sodu viduryje ir pavėsine parko vakarinėje dalyje. 


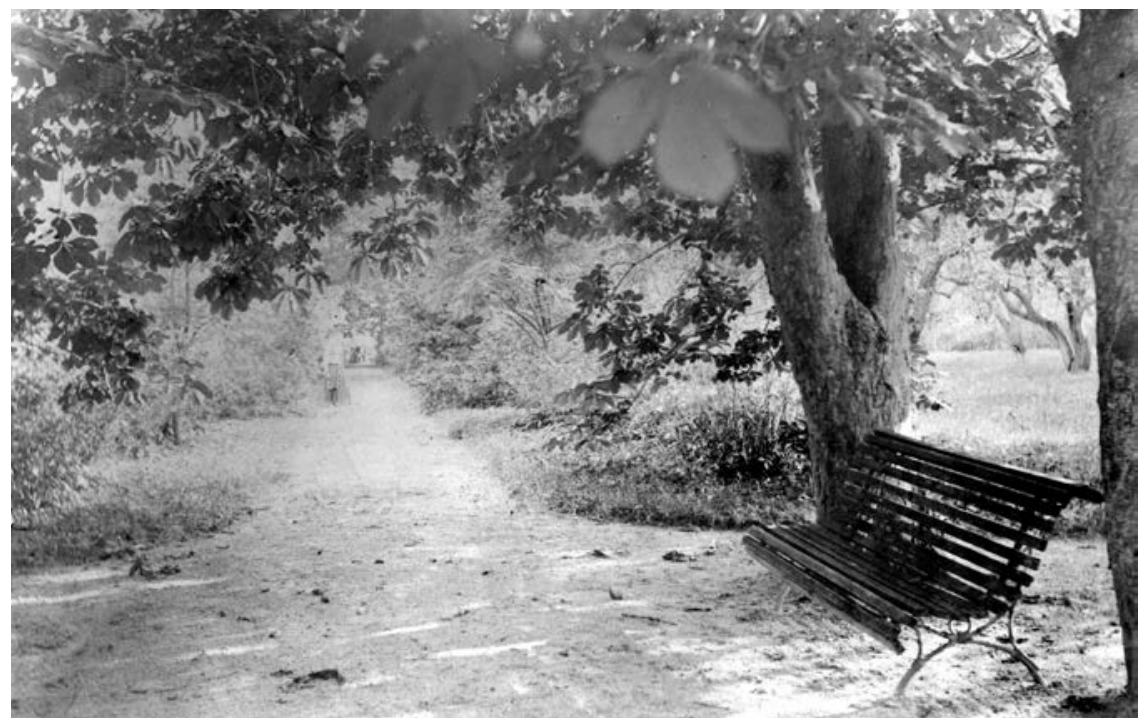

17.

Parko kaštonu aleja, apie 1910, Johano Grothuso Chestnut alley in the park ca. 1910 nuotrauka

Čia slypejjo dvaro dvasia. Visa tai, tikriausiai iki paskutinio medžio, buvo sodinta ir auginta Sūrumų Gederto. İeini i jị (aš pati jị išvaikščiojau 2 kartus - viena ar su Mildute) ir junti šventą pagarbą žmogaus darbui ir jo šilumai, kuri ir dabar juntama pavasariais, kai sužydi Gederto kaštonai [17, 18 il.].

Kaip ponai leido laiką?

Valgè, gèrè, žiūrèjo per langą. Vaikštinèjo, šildèsi saulèje ir prie židinio. Miegojo neribotai ir bereikalingai. Klausėsi dvaro ir po apylinkes klajojančių muzikantų, žiūrèjo klajojančių meškų ir beždžionių dresuotojų pasirodymus. Dažnai važinėdavo ị Jelgavą, Bauskę, Šiaulius. Dažnai lankėsi svečiuose pas kitus Grothusus, kurie buvo įsitvirtinę visoje Latvijoje. Priimdavo svečius ir valandų valandas tuščiai šnekučiuodavosi. Vyrai žaidè šachmatais, fechtavosi. Moterys besaikiai „patarnavo“ mados dievui. Senoji baronienė dvaro žmonėms „dèjo ragus“ (žvakes) ir „kraujagysles leidusi“ (iš venos nutekindavo „blogą“ kraują). Vyrai dar žvejojo, medžiojo ir dienų dienas praleisdavo įvairiuose dvarininkų susirinkimuose. 


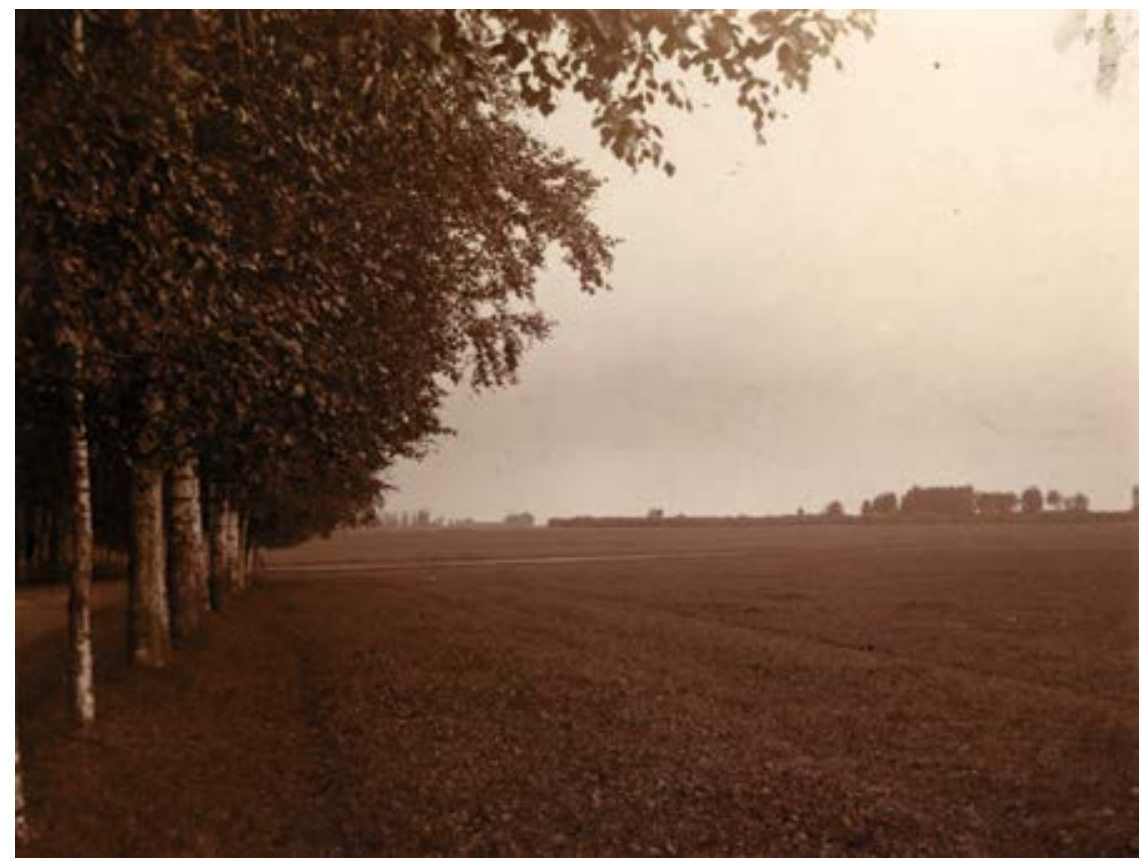

18.

Lieporų dvaro sodybos šiaurinè dalis, ịvažiavimas

Northern part of the Lieporai manor property, the entryway is flanked by the birch alley, in the front, a road to Mitau (Jelgava) via the Juodeikiai Manor, ị sodybą ribojamas beržų alèjos, priekyje vieškelis i Mintaują pro Juodeikių dvarą, apie 1910, Johano Grothuso nuotrauka ca. 1910

Tačiau tarnams darbo netrūko nei dieną, nei vakare. Vakarais dvaro mergos mušè sviestą, plikė vištas, pešè plunksnas, verpè, siuvinėjo, audė aišku, ponams. Neretai šeimininkė visus darbus prižiūrèdavo. Jei kuri merga nuo monotoniško darbo vakare užmigdavo, už tai ausies nebetampė kaip senais Grothusų laikais, bet per Kalèdas, kai tarnams buvo dalijamos dovanos, ne tik kaltininkè, bet ir visi matydavo, kad ši „nuodèmè“ neužmiršta. Ir dvaro tarnams bendrajame kambaryje darbo netrūko. Ponų kambariuose laikrodžiai jų laiką lètai suko. Tarnų kambariuose laikas tekejjo, laikrodžiu nematuojamas. Čia visuomet jo trūko net ir savo gyvenimui, o ir naktis kasdien pasibaigdavo ryte anksčiau. Visa tai ir tokiame dvare, kokie buvo Lieporai, ir prie „gerų“ ponų, kokie buvo Grothusai. 
Anelè ir Karlis nepriklausė tai tarnų kategorijai, kurią aš priešinu baronams. Anelè valgè prie II stalo ir vakarais jai nereikejjo dirbti šeimyninëje. Karlis nevalgydavo prie ponų stalo, jam motina gamino namuose. Vakarai po pokalbių su ponu, kurie ịprastai vykdavo apie 8 val. vakaro, prievaizdui buvo laisvi9 ${ }^{92}$.

Gauta 20201031

92 Melānija Vanaga, Dvēseļu pulcēšana. Iedzīvoju pasakā, Rīga: Jumava, 2017, p. 124, 128-131. Iš latvių kalbos vertè Ernestas Vasiliauskas. 


\section{Nepublikuoti šaltiniai}

Actt inwentarza od jego mosci pana Druwa straznika Xięstwa Zmuydskiego jego mosci Panu Treydanowi podczaszemu pinskiemu z pani małzące jej mości słuzącego, 16441645/1694, in: LVIA, SA-39, 1. 405-406v.

Akt inwentarza poddanych przy prawie wieczystym od ich mosci panow Sakinow małzonkow jego mosci panu Frankowi danego, 177909 09, in: LVIA, SA-68, 1. 1202-1203v.

Aktykacia listu dzielczego ich mosci panom Druwom służącego, 175707 05, in: LVIA, f. 285 , ap. 1, b. 58 (SA-14555), l. 138-139v.

Biržų, Pabiržès ir Brunavos parapijų žemèlapis, 1812, in: LVIA, f. 525, ap. 8, b. 1582, 1. 10.

[Grotthuss Alexander] ${ }^{93}$, Erinnerungen aus der Hand von Alexander Julius Otto Baron v. Grotthuss (*Leeparn 16.11.1855, †Pokroy 21.10.1933). Endbearbeitung durch Michael Alexander Baron v. Grotthuss, 2008 [mašinraštis].

Grotuzas Vilhelmas, in: LCVA, f. 1248, ap. 2, b. 1845 .

[Jankus, Gerardas Bagdonavičius, Šiaulių apskr. dvarų inventorizacija, Šiauliai, 1940], in: Kultūros paveldo centras, f. 17, ap. 2, b. 11.

Kriukų vls. Lieporių dv. 1. Dvaro, Albertiškių ir Miežinių palivarkų parceliacijos planas (1:5000), 1929, in: LCVA, f. 1250, ap. 4, b. $13 / 261$.

Kurzemes brunniecības arhīvs (1656-1938). Franck-Pfeilitzer. 19. gs. in: LVVA, f. 640, ap. 3 , b. 97 .

Lieporių dvaras, in: LCVA, f. 1248, ap. 20, b. 2226.

Muižnieku dzimtu dokumenti. Grothusu dzimtas arhīvs. Dzimtas genealogiskas tabulas, 1570-1872, in: LVVA, f. 1100, ap. 6, b. 6.

Muižnieku dzimtu dokumenti. Grothusu dzimtas arhīvs. Dokumenti (revīzijas lapas, lūgums, kvīts) par dvēselu revīziju Pograničas muižā, 1811-1850, in: LVVA, f. 1100, ap. 6, b. 23 .

Muižnieku dzimtu dokumenti. Grothusu dzimtas arhīvs. Dzimtas genealogiskas tabulas par 16.-19. gs., in: LVVA, f. 1100, ap. 6 , b. 36 .

Muižnieku dzimtu dokumenti. Pfeilitceru-Franku dzimta. Dokumenti (ziņojumi, testamenti, līgumi u.c.) par nekustamā īpašuma mantošanu, 1626.-1880, in: LVVA, f. 1100, ap. 13, b. 1085.

Muižnieku dzimtu dokumenti. Pfeilitceru-Franku dzimta. Dokumenti (spriedums, protests, protokoli) par dzimtas loecklu kārtotajiem juridiskajiem jautājumiem. 1666.-1810, in: LVVA, f. 1100, ap. 13, b. 1101.

Materiāli par personām Rīgā un Baltijas provincēs. Pfeilitzer, 1748.-1878, in: LVVA, f. 4011, ap. 1, b. 4278.

Naugarduko, Minsko ir Trakų vaivadijų bei Lydos, Upytės, Oršos ir Rečicos pavietų dūmų ir padūmès mokesčio tarifai (Nowogrodzkie, Minskie, Trockie województwa, Lidzki, Upitski, Orzszanski i Rzeczycki powiaty), 1775, in: LVIA, f. 11, ap. 1, b. 1588 (SA-18167).

Pašvitinio bažnyčios inventorius, 172510 16, in: LVIA, f. 1671, ap. 4, b. 424, 1. 5-8v.

Pašvitinio ir Linkuvos parapijų žemėlapis, 1812, in: LVIA, f. 525, ap. 8, b. 1582, l. 13.

Przyznanie wieczysto ugodliwego zapisu między jegomosci panami Tyzenhauzami y Frankami zaszłego, 176807 18/1773 07 16, in: LVIA, f. 351, ap. 1, b. 8 (SA-15269), 1. 209-216.

Przyznanie inwentarza majętnosci Lepar od jegomosci pana Tyzenhauza y Frankow jegomosci panu Tyzenhauzowi danego, 176806 23/1773 07 16, in: LVIA, f. 351, ap. 1, b. 8 (SA-15269), 1. 217-218.

Przyznanie inwentarza majętnosci Lepar od jegomosci pana Tyzenhauza jegomosciom panom Frankom danego, 177105 05/1773 07 16, in: LVIA, f. 351, ap. 1, b. 8 (SA-15269), 1. 219-220.

Przyznanie wieczysto przodaznego prawa na dobra Albrychtow alias Lepary od jegomosciow panow Grotuzow jegomosci panom Frankom danego, 177110 14/1773 07 16, in: LVIA, f. 351, ap. 1, b. 8 (SA-15269), l. $221-223$.

93 Laužtiniuose skliaustuose ịvardytas žinomas, bet nepasirašęs autorius, be to, neịvardytas dokumento pavadinimas. 
Przyznanie inwentarza majętnosci Lepar, Albrychtowa seu Lepar od wielmoznych Frankow wielmożnemu Frankowi danego, 177703 15, in: LVIA, f. 351, ap. 1, b. 12 (SA15273), 1. 141-147.

[Sutartis dèl Lieporų (Anuševičių) dvaro pardavimo], 174104 04, in: LVIA, SA-15347, 1. $48-51$.

[Sutartis dèl Lieporų (Albrechtavo) dvaro pardavimo], 176304 03, in: LVIA, SA-15351, 1. 341-344.

Upytės pavieto dūmų tarifas (Taryfa dymów), 1790, in: LVIA, f. 11, ap. 1, b. 707 (SA-3370).

Viliaus Grotuso ịpèd., in: LCVA, f. 1248, ap. 2, b. 1844 .

Vokiečių tautybès savininkų ūkių atskirose apskrityse sąrašai, 1940-1941, in: LCVA, f. R-764, ap. 1a, b. 153.

Выписки из инвентарей помещичьих имений и расписки владельцев о принятии инвентарных правил по Шавельскому уезду, 1848/1854, in: LVIA, f. 378, BS-1848, b. 2118.

Дело об исчислении расходов на составление ревизских сказок и о злоупотреблениях казенной палаты. Сведения о количестве дымов и душ по имениям, 1816-1826, in: LVIA, f. 391, ap. 6, b. 123.

Дело о выдаче ссуды барону Гротус Ф. А. в залог им. Лепары Шавельского у. Ковенской губ., 1885-1894, in: LVIA, f. 542, ap. 1, b. 262 .

Дело о перезалоге им. Лепары Шавельского у. Ковенской губ. барона Гротуса Ф. А., 1907-1916, in: LVIA, f. 542, ap. 1, b. 943 , 1. 25-26, 29.

Карта Шавельского у. Ковенской губернии, 1843, in: LVIA, f. 526, ap. 7, b. 5444.

\section{Publikuoti šaltiniai}

Beschreibung der Provinz Kurland: Nach Anleitung des unter Allerhöchsten Schutz Seiner Kaiserlichen Majestät von Einer freien ökonomischen Gesellschaft zu St. Petersburg im Jahr 1802 angefertigten Entwurfs, Hrsg. Keyserling P. von; Derschau Ernst von, Mitau: J. F. Steffenhagen und Sohn, 1805.

Genealogisches Handbuch der baltischen Ritterschaften. (Herausgegeben von Verbänden des livländischen, estländischen und kurländischen Stammadels). O. Stavenhagen, heraus, Bd. 2: Kurland: 1930-1944, Görlitz: Verlag für Sippenforschung und Wappenkunde G. A. Strake (Inh. Hans Kretschmer), [1944], Lies. 9.-12.

Genealogisches Handbuch der Freiherrlichen Häuser, Hauptbearbeiter: Walter v. Hueck, Bd. VI: Stammfolge des Geschlechts der Freiherren v. Grotthu $\beta$, Limburg a. d. Lahn: C. A. Starke Verlag, 1966.

Lietuvos apgyventos vietos: pirmojo visuotinojo Lietuvos gyventoju $1923 \mathrm{~m}$. surašymo duomenys, sud. Biržiška V., Kaunas: Centralinis statistikos biuras, 1925, t. VIII.

Richter Adolf, Adolf Richters Baltische Verkehrs- und Adressbücher, Bd. 2: Kurland, 1912, Riga: Selbstverlag des Herausgebers.

Rusmanis Sigurds, Zeme starp Rundāli un Tèrveti, Rīga: Jumava, 2006.

Vanaga Melānija, Dvēseļu pulcēšana. Iedzīvoju pasakā, Rīga: Jumava, 2017.

XVI amžiaus Lietuvos inventoriai, sud. Konstantinas Jablonskis, Kaunas: Menas, 1934, t. I.

Алфавитный список землевладельцев Ковенской губернии (по 1-е сентября 1881 года),

Ковно: Типография губернского правления, 1882.

Алфавитный список населенных месть Ковенской губернии, Ковно: Типография губернского правления, 1903.

Описъ документовъ Виленскаго центрального архива древнихъ актовыхъ книгъ, Вильна:
$97-2020$

Acta Academiae Artium Vilnensis 
Типографія Бр Д. и Х. Яловцеръ, 1909, t. VII.

Описъ документовъ Виленского иентрального архива древнихъ актовыхъ книгъ, Вильна: Типографія Бр Д. и Х. Яловцеръ, 1912, t. VIII.

\section{Literatūra}

Błaszczyk Grzegorz, Herbarz szlachty Żmudzkiej, t. I: $A-F$, Warszawa: DIG, 2015.

Čelkis Tomas, Antanavičius Darius, „1545 metu Livonijos ir Lietuvos Didžiosios Kunigaikštystès sienos patikrinimas (Livonijos pareigūnų ataskaita)“, in: Lietuvos istorijos studijos, Vilnius: Vilniaus universiteto leidykla, 2011, Nr. 27, p. 164-178.

Jansone Ilga, „Krievinii un to atstātās pēdas Zemgalē“, in: Raksti, t. V: Starptautiskās zinātniskās konferences zinātniskie lasījumi G. Eliasa Jelgavas vēstures un mākslas muzejā materīāli, Jelgava: G̦. Eliasa

Jelgavas vēstures un mākslas muzejs, 2008, p. $47-57$.

Jovaiša Liudas, „Kriukų Šv. Lauryno bažnyčios istorija“, in: Lietuvos sakraline daile, t. II: Šiauliu vyskupija, d. 1: Joniškio dekanatas, kn. 2: Juodeikiai-Rudiškiai, sud. Dalia Vasiliūnienė [ir kt.], Vilnius: Lietuvos kultūros tyrimų institutas, 2012, p. 155-184.

Jučas Mečislovas, Baudžiavos irimas Lietuvoje, Vilnius: Mintis, 1972.

Jurginis Juozas, Baudžiavos įsigalejimas Lietuvoje, Vilnius: Valstybinè politinès ir mokslinès literatūros leidykla, 1962.

„Kreewini“, In: Konwersazijas wahrdniza, Rīga, 1908, t. 2, p. 124.

„Krieviņi“, in: Latviešu konversācijas vārdnīca, Rīga: A. Gulbis, 1933, t. 9,p. 18339-18340.

Kurländische Güter-Chroniken. Neue Folge. Kautzmünde, Ruhenthal, Schwitten, Mitau:

E. Behre's Commissions-Verlag, 1899, Lies. I.

Kursìte Janīna, Neakadēmiskā latviešu valodas vārdnīca jeb novadu vārdene, Rīga:

Madris, 2007.

Lancmanis Imants, Rundāles pils, Rundāle: Rundāles pils, 2007.

Lancmanis Imants, Svitenes muiža. Bērsteles muiža. Schwitten. Gross-Bersteln, Rundāle: Rundāles pils muzejs, 2003.

Lietuviu pavardžiu žodynas, t. 2: $L-\check{\text {, }}$ ats. red. A. Vanagas, Vilnius: Mokslas, 1989.

Lietuvos dailininku žodynas, t. III: 1918-1944, sud. Lijana Šatavičiūtè-Natalevičienè, Vilnius: Lietuvos kultūros tyrimų institutas, 2013.

Misius Kazys, „Vietovès“, in: Joniškio kraštas: Enciklopedinis žinynas, sud. ir ats. red. Vytautas Didžpetris, Kaunas: Žiemgalos leidykla, 2011, p. 47-127.

Reise nach Livland und Kurland zur genauen Untersuchung der Reste der Liwen und Krewingen, von A. J. Sjögren, Weimar, 1847.

Schroeders Percy, Nachrichten über Kurländer in Litauen, München: Kurländische Ritterschaft, 1984.

Sitzungsberichte der kurländischen Gesellschaft für Literatur und Kunst aus dem Jahre 1881, Mitau: J. F. Steffenhagen und Sohn, 1882.

Šimoliūnas Aleksandras, „Iš Joniškio krašto dvarų istorijos. Lieporų dvaras“, in: Žemygala, 2010, Nr. 1 (9) - 2 (10), p. 34-39.

Šliavas Juozas, Žiemgaliu pédsakais, Vilnius: Žiemgala, 1996.

Šterns Indriķis, Latvijas vēsture. 1290-1500, Rīga: Daugava, 1997.

Trimonienė Rita Regina, „Svetimšalių ir svetimtaučių bajorų imigracija ị Žemaitiją XVI a. antrojoje pusejje - XVII a. pirmojoje pusėje: imigracijos kultūriniai veiksniai ir ịtakos žemaičių visuomenei“, in: Rytu Europos kultūra migracijos kontekste: tarpdalykiniai tyrimai, sud. Irena Regina Merkienè, Vilnius: Versus aureus, 2007, p. 491-514.

Vasiliauskas Ernestas, „Lieporų (Joniškio r.) kapinyno radiniai (VI-XI a.)“, in: Lietuvos 
archeologija, Vilnius, 2007, t. 30, p. 213-228.

Vasiliauskas Ernestas, „Grafų Keyserlingku ir kitų Lietuvos dvarininkų archeologiniai rinkiniai Kuršo provincijos muziejuje“, in: Archaeologia Lituana, Vilnius, 2015, t. 16, p. 102-136.

Wiedemann Ferdinand Johann, Über die Nationalität und die Sprache der jetzt ausgestorbenen Kreewinen in Kurland, St.-Pétersbourg: Eggers in Komm, 1871.

III rudens dailes paroda: Kaunas $1937 \mathrm{~m}$. gruodžio mèn. 19 d. - 1938 m. sausio mén. 16 d., Kaunas: Vytauto Didžiojo kultūros muziejus, [1937]. 


\title{
Summary
}

\section{The Lieporai Manor, A Residence of the Barons von Grotthuss}

\author{
Ernestas Vasiliauskas
}

Keywords: Lieporai (Leeparn), okolica, manor, Druwe, von Grotthuss.

The development of housing and, alongside, the appearance and development of manors at the border of Livonia and the Grand Duchy of Lithuania have so far not received enough research attention. After the Battles of Grunewald in 1410 and Wilkomierz in 1435, which marked the end of intense fighting in these lands, the Bauska Castle was built in the middle of the $15^{\text {th }}$ century, and the processes of colonisation started. The Votic people of Finnish origin (German Kreewing, Latvian krievini ) were settled in the sparsely inhabited territory of Eastern Semigallia. The intensifying deforestation and the densifying network of settlements brought about a need for border regulations $(1426,1473$, $1529,1541,1545,1582,1583-1586,1587)$. At the same time, in the $15^{\text {th }}$ century, the Livonian Order started to distribute manor properties in Semigallia to its vassals. The earliest recorded Finno-Ugric form of the name of the Lieporai Man-

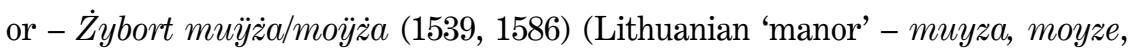
dialectal muižè, Livonian moize, mois, Estonian mõis, Votic moise, mõiza) is most likely related to these colonisation processes.

The Lieporai field in the Upyte powiat appeared in written sources in the $16^{\text {th }}$ century. In earlier sources (e.g., the $15^{\text {th }}-16^{\text {th }}$ century border agreements between the Grand Duchy of Lithuania and Livonia), this place name is not mentioned. Until the end of the Teutonic wars in 1290, this territory belonged to Eastern Semigallia - the Upmale land, and, quite likely, was its composite part - district. It might have taken its name from the Lieporas rivulet (in the $13^{\text {th }}$ century sources, only the Plone land with the Šiurpe and Guostagalis castle districts are mentioned in this part of Upmale). In the times of Livonia and the Grand Duchy of Lithuania, in the $14^{\text {th }}-16^{\text {th }}$ century, the Lieporai dis- 
trict became a field, in which smaller economic-administrative units - manors - were gradually formed. The cartography of the toponyms mentioned in the Upytè castle and district court books from 1584 to 1615 reveals that the Lieporai field between the Šešèvė and Švitinis Rivers might have extended over an area of circa 5,705 hectares.

Gradually, between the $16^{\text {th }}$ and $19^{\text {th }}$ century, seven units (manors) were formed in the Lieporai field. They have retained their original names: the private Lieporai manors of von Grotthuss and Brasch (the last owners), Albertiškiai (Albrychtowo alias Lepar), Medvilionys (from the $17^{\text {th }}$ c. until 1769 also called Lieporai - Medwitany alias Lepary), Lieporai noble village (with 10-11 hearths), as well as Juodeikiai, Vengriškiai, and the Samogitian bishop's Kriukai, which most likely were later renamed.

The Lieporai manor changed hands and names many times. The earliest known owners of the manor, which was then called Žybartai ( $\dot{Z}$ ybort mö̈ża alias Lepary w okolicy Leparach), were the Druwe family (Polish Druwa, Druw, Druf, Druff, German Druwe, Traube), mentioned in the Upytè court books of 1653, where it was indicated that the master of the Livonian Order, Hermann von Bruggenei (alias Hasenkamp, 1535-1549), by a privilege of 1539, granted the manor, since olden times called $\dot{Z} y b o r t$ mü̈za at the border of Courland [Livonia] and Lithuania, as a fief to Jan Druwa for his honest service. According to a border correction adopted by King Stephen Báthory's commission for regulating the border between the Polish-Lithuanian Commonwealth and Courland in 1583/1586, the manor property was transferred from Livonia to the Grand Duchy of Lithuania and granted to the Curonian knight Jodok Druwe with the inheritance rights. The Lieporai Manor was owned by the noble Druwa family (in 1661-1685/1717, it was also called Karklynè (Karklien)) from 1539 to 1666/1676, followed by von Pfeilitzer gen. Franck, in 1666/1676-1826/1834, von Tiesenhausen in 1763-1773, and finally, von Grotthuss in 1826/1834-1940. Otto Ewald Friedrich von Grotthuss (1774-1848, Berstele line) who acquired the Lieporai Manor circa 1826/1834 is considered to be the founder of this branch.

The earliest known reference to the manor at the Lieporas rivulet can be found in a complaint of 30 August 1586. There are more data about the Lieporai manor property from the $18^{\text {th }}$ century. Yet, the sale-purchase acts com-

$97-2020$

Acta Academiae Artium Vilnensis 
piled at that time, compared to those of the Daunorava or Malgūžiai (1763) and Wigandt's Lieporai (1759) Manors, do not include detailed inventories of the Lieporai (Grotthuss) Manor, and the cultivated crops are not listed. In 17631773, the Lieporai-Albrechtavas Manor was a separate property (without the large villages of Gailiūnai and Sodininkai and the Karklynė folwark), and its lands were situated on the site of the later known Albertiškès folwark. Between 1768 and 1775, in the times of Pfeilitzer gen. Franck, this property was connected to Lieporai-Karklynė, owned by the same family. In 1854, the Grotthuss's Lieporai manor property extended over 1,037 dessiatins of land, of which 18 dessiatins were farmhouses with gardens and vegetable gardens, 270 - arable land, and 108 were fields, and included the villages of Andrešiūnai, Andriejūnai (Indriliūnai), Maželiai, Sodininkai and Gailiūnai (in total 18). The plan of the Lieporai property compiled in 1885 (the situation after the peasant reform of 1861) shows a property east of the Lieporas rivulet, compactly extending towards the north-south. Before the land reform of 1922, the estate had an area of 429.51 hectares, of which 151 hectares remained not appropriated.

The structure of the Lieporai estate (an irregular trapezoid shape), as can be seen from the cartographic material, dates to the late $17^{\text {th }}$ and $18^{\text {th }}$ century and has some adopted baroque features - buildings from the periods of classicism and historicism encircling an open rectangular courtyard. From the $19^{\text {th }}$ century until 1940, like other medium-sized manor estates, it consisted of four parts: 1) the main courtyard (with the master's house, a storage barn, an overseer's house-servants' quarters, a house for farmhands and a flowerbed in front - a new classicist element); 2) an adjacent auxiliary courtyard with cattle-sheds and a barn; 3 ) to the north east, a more remotely located production zone with a forge; 4 ) to the east, a barnyard. A root-crop garden was planted next to the auxiliary courtyard, on the south side. From the south, the manor estate was surrounded by a landscape park with a garden, and on the east side, there were ponds and a hothouse, in total, 15-27 buildings. The park had a specially designated place for beehives and for burying dogs and horses, and water fowl lived on the ponds (an aviary was nearby). The estate could be accessed from the Kriukai-Žeimelis road, and from the west side - by a planted birch alley. 